\title{
Fear and stressing in predator-prey ecology: considering the twin stressors of predators and people on mammals
}

\author{
Loren L Fardell ${ }^{\text {Corresp., } 1}$, Chris R Pavey ${ }^{2}$, Chris R Dickman ${ }^{1}$ \\ ${ }^{1}$ School of Life and Environmental Sciences, University of Sydney, Sydney, NSW, Australia \\ 2 Land and Water, CSIRO, Winnellie, Northern Territory, Australia \\ Corresponding Author: Loren L Fardell \\ Email address: Ifar3796@uni.sydney.edu.au
}

Predators induce stress in prey and can have beneficial effects in ecosystems, but can also have negative effects on biodiversity if they are overabundant or have been introduced. The growth of human populations is, at the same time, causing degradation of natural habitats and increasing interaction rates of humans with wildlife, such that conservation management routinely considers the effects of human disturbance as tantamount to or surpassing those of predators. The need to simultaneously manage both of these threats is particularly acute in urban areas that are, increasingly, being recognized as global hotspots of wildlife activity. Pressures from altered predator-prey interactions and human activity may each initiate fear responses in prey species above those that are triggered by natural stressors in ecosystems. If fear responses are experienced by prey at elevated levels, on top of responses to multiple environmental stressors, chronic stress impacts may occur. Despite common knowledge of the negative effects of stress, however, it is rare that stress management is considered in conservation, except in intensive ex situ situations such as in captive breeding facilities or zoos. We propose that mitigation of stress impacts on wildlife is crucial for preserving biodiversity, especially as the value of habitats within urban areas increases. As such, we highlight the need for future studies to consider fear and stress in predator-prey ecology to preserve both biodiversity and ecosystem functioning, especially in areas where human disturbance occurs. We suggest, in particular, that non-invasive in situ investigations of endocrinology and ethology be partnered in conservation planning with surveys of habitat resources to incorporate and reduce the effects of fear and stress on wildlife. 
1

2 Fear and stressing in predator-prey ecology: considering the twin stressors of predators

3 and people on mammals

4 Loren L. Fardell ${ }^{1}$, Chris R. Pavey ${ }^{2}$, Chris R. Dickman ${ }^{1}$

5

$6 \quad{ }^{1}$ School of Life and Environmental Sciences, University of Sydney, NSW 2006, Australia.

$7 \quad{ }^{2}$ CSIRO, Land and Water, PMB 44 Winnellie, 0822, Northern Territory, Australia.

8

9 Corresponding author:

10 Loren L. Fardell ${ }^{1}$

11 University of Sydney, Heydon-Laurence Building (A08), Room 325, Camperdown, NSW 2006, Australia.

12 Email address:loren.fardell@gmail.com

13

14

15

16

17

18

19

20

21

22

Peer) reviewing PDF | (2019:09:41203:3:0:NEW 9 Apr 2020) 


\section{Abstract}

24 Predators induce stress in prey and can have beneficial effects in ecosystems, but can also have

25 negative effects on biodiversity if they are overabundant or have been introduced. The growth of

26 human populations is, at the same time, causing degradation of natural habitats and increasing

27 interaction rates of humans with wildlife, such that conservation management routinely considers

28 the effects of human disturbance as tantamount to or surpassing those of predators. The need to

29 simultaneously manage both of these threats is particularly acute in urban areas that are,

30 increasingly, being recognized as global hotspots of wildlife activity. Pressures from altered

31 predator-prey interactions and human activity may each initiate fear responses in prey species

32 above those that are triggered by natural stressors in ecosystems. If fear responses are

33 experienced by prey at elevated levels, on top of responses to multiple environmental stressors,

34 chronic stress impacts may occur. Despite common knowledge of the negative effects of stress,

35 however, it is rare that stress management is considered in conservation, except in intensive ex

36 situ situations such as in captive breeding facilities or zoos. We propose that mitigation of stress

37 impacts on wildlife is crucial for preserving biodiversity, especially as the value of habitats

38 within urban areas increases. As such, we highlight the need for future studies to consider fear

39 and stress in predator-prey ecology to preserve both biodiversity and ecosystem functioning,

40 especially in areas where human disturbance occurs. We suggest, in particular, that non-invasive

41 in situ investigations of endocrinology and ethology be partnered in conservation planning with

42 surveys of habitat resources to incorporate and reduce the effects of fear and stress on wildlife. 
45 Predators in many systems positively influence the local distribution and abundance of their prey

46 (e.g. Polis et al., 1998; Ayal, 2007; Estes et al., 2011; Weissburg, Smee \& Ferner, 2014), and

47 indirectly but positively influence the functioning of whole ecosystems via trophic cascades

48 (Prugh et al., 2009; Ritchie \& Johnson, 2009; Estes et al., 2011; Ripple et al., 2014). Predators

49 often elicit fear responses in prey that affect prey behaviour, energy budgets and the way they

50 interact with the environment (Brown \& Kotler, 2004; Clinchy et al., 2004; Romero, 2004). For

51 example, the fear response of an individual of a prey species to a predator may be to change the

52 locations or times in which they forage, which can have positive impacts on the structure of the

53 environment (Laundré, Hernández \& Ripple, 2010). Such fear responses can in turn influence

54 ecosystem function (Schmitz, Krivan \& Ovadia, 2004, Schmitz et al. 1997, Hawlena et al.,

55 2012). These effects arise due to the 'landscape of fear' that prey individuals perceive - that is,

56 the spatial distribution of perceived predation risk that influences prey movement and behaviour

57 as prey individuals attempt to mitigate risk and obtain essential resources (Laundré, Hernández

58 \& Altendorf, 2001; Laundré, Hernández \& Ripple, 2010).

59 Recent studies suggest that the effects of predators are being altered, and often amplified,

60 by human activities. For example, the demise of top predators in many parts of the world has

61 'released' populations of smaller predators, or mesopredators that have since become

62 overabundant and now exert strong pressure on smaller species (Prugh et al., 2009). Predators

63 that have been introduced to new areas also exert much stronger pressure on prey populations

64 than do native predators (Salo et al., 2007). Climate change and associated shifts in primary

65 productivity can also have bottom-up impacts on predator-prey interactions (Laws, 2017). Such

66 novel alterations to predator-prey dynamics can depress prey populations and disrupt community 
67 structure, and as such require novel approaches to recognize and manage their effects (Carthey \&

68

69

70

71

72

Blumstein, 2018; Fleming \& Bateman, 2018; Guiden et al., 2019).

Altered predator-prey interactions may contribute to declines in biodiversity, but a primary cause of biodiversity loss is the rapid global increase in human populations, driving agricultural, industrial, and urban expansions that change or destroy natural habitats (Madsen et al., 2010). Such expansions are resulting in novel human - wildlife interactions and secondary impacts that arise from human activities in close proximity to natural environments, and thus increasingly are becoming an additional stressor that influences ecosystem function. Pressures exerted both directly and indirectly by human activities have been likened to the pressures exerted by the presence of a top predator on prey (e.g. Frid \& Dill, 2002; Rehnus, Wehrle \& Palme, 2014; Patten \& Burger, 2018). Natural predation pressures coupled with human-imposed predation-like pressures and / or additional exogenous stressors, such as pollution, arising from anthropogenic activities are likely to negatively affect prey species by increasing their levels or frequency of stress. Current research is developing a more nuanced understanding of the effects of human activity and predator presence on the stress of prey (e.g. Arlettaz et al., 2015; Jaatinen, Seltmann \& Öst, 2014, respectively). However, few studies in terrestrial ecosystems have considered both of these pressures simultaneously or have linked behavioural responses with endocrinological evidence of stress. In one instructive recent study, human activity was shown to be positively correlated with physiological stress in ungulates, whilst in areas occupied by large predators stress was found to be lower and less variable (Zbyryt et al., 2017).

Conservation management and associated scientific research is often viewed from the perspective of a single discipline. However, ecological changes arising from anthropogenic disturbances, including the alteration of predator-prey encounter rates, creation of novel species 
90 interactions (including between people and wildlife), introduction of novel species, and the

91 alteration of natural habitats, call for multidisciplinary solutions. This is particularly pertinent as

92 urban edge habitats are becoming increasingly valuable global hotspots of wildlife activity (Ives

93 et al., 2016), and human influences are spreading further into natural habitats (Otto, 2018). There

94 is growing evidence that multiple introduced stressors (e.g. altered predator-prey interactions and

95 disturbance from humans) can have compounding impacts on wildlife, especially when

96 interacting with natural stressors in ecosystems (Geary et al., 2019). For these reasons, it is

97 timely to review relevant information from the broad knowledge bases of conservation

98 physiology, ethology, and ecology to communicate the urgent need for wildlife managers and

99 urban planners to routinely consider how fear and stress effects from multiple sources,

100 particularly novel predator interactions and human activities, can affect prey species and

101 ecosystem functioning in increasingly altered systems. Our focus in this review is on mammals

102 because of the wealth of information on this group, but we note relevant studies from other

103 groups where appropriate. We begin our review by describing physiological responses of

104 mammals to fear and stress, then we consider the behavioural responses of mammals to these

105 factors, and argue that human activity should be considered as part of the ecosystem so that

106 overall stress impacts can be managed accordingly. We then demonstrate how fear and stress can

107 influence habitat use, how vegetation and microhabitat management potentially may be used to

108 alleviate stress, and how to monitor for fear and stress to then create management change.

109 Finally, we use Australia as an example to show the benefits of considering cumulative fear and

110 stress impacts to mitigate the effects of introduced eutherian predators, increased human activity,

111 and the possible interactive effects of the two. 


\section{Review method}

114 This is not a systematic review, but rather a novel synthesis of existing knowledge. It seeks to

115 extend ideas on the physiological impacts of fear and stress, behavioural ecology, predator-prey

116 dynamics, and conservation management to explore the influence of humans and altered

117 predator-prey interactions in the urban environment. To ensure that all key topic areas were

118 thoroughly covered we conducted literature searches via: Google Scholar ${ }^{\odot}$, Web of Science ${ }^{\odot}$,

$119 \mathrm{JSTOR}^{\odot}$, and Wiley Interscience Online Library ${ }^{\odot}$. Manuscripts were mined for information

120 relevant to wildlife fear and stress in terms of ecological management under anthropogenic

121 pressures, including introduced predators and altered predator-prey interactions. The literature

122 searches were undertaken using the following key terms as part of their title, keywords, and / or

123 within the abstract: "acute stress", "chronic stress", "homeostasis", “cumulative stress",

124 "multiple stressors", "multiple threats", "allostatic load", "allostatic overload", "acclimitisation",

125 "glucocorticoid response", "hypothalamic pituitary adrenal axis", "fear arousal", "fear

126 evolution", "fear predation”, “amygdala" "fear", "Pavlovian fear conditioning”, "glucocorticoid

127 assay", "f(a)ecal glucocorticoid", "non-invasive glucocorticoid assay", "reactive scope model",

128 "landscape(s) of fear", "risk allocation hypothesis", "olfaction" + "fear" + "mammal”, "post-

129 traumatic stress disorder", "predator" + "odo(u)r" + "fear", "predator cue(s)", "predation stress

130 hypothesis", "predator-sensitive food hypothesis", "human activity" + "stress" + "wildlife",

131 "human disturbance", "interactive stress", "multiple stress(ors)", "additive stress impacts",

132 "synergistic stress impacts", "antagonistic stress impacts", "human" + "wildlife" + "resource

133 subsidies", "predator trophic cascade", "wildlife urban adaptation", "urban ecology" +

134 "wildlife", "Australian mammal extinction", "critical weight range mammal", "diet" + "change"

135 + "Australian" + "predator", "red fox" + "Australia", "domestic cat" + "Australia", "human 
136 activity" + "wildlife" + "Australia", "Australia" + "biodiversity" + "conservation policy" +

137 "urban hotspot", "Australian environment protection and biodiversity conservation act" +

138 "cumulative stress", "Australia" + "conservation" + "glucocorticoids", "introduced predator

139 control", "habitat structural complexity", "habitat structural diversity", "vegetation diversity",

140 "vegetation heterogeneity", "habitat heterogeneity hypothesis", "cumulative effects

141 assessments". Supplementary articles supporting the review narrative, suggested by reviewers on

142 earlier versions of the manuscript, have also been included.

\section{Mammalian physiological responses to fear and stress}

145 Physiological stress can be broadly defined as a change in the physiological well-being of an

146 individual following exposure to an aversive extrinsic stimulus - frequently referred to as a

147 stressor (Seyle, 1936). The physiological stress response that follows aims to restore internal

148 homeostasis (Cannon, 1932). An individual animal experiences stress in response to conditions

149 that threaten its survival or compromise its ability to maintain homeostasis. Examples include

150 acute or chronic encounters with predators, inclement weather, significant natural disturbances

151 including fire and flood, reduced oxygen availability, and depleted food resources (Lima, 1998;

152 King \& Bradshaw, 2010; Malcolm et al., 2014; Santos et al., 2014; Crocker, Khudyakov \&

153 Champagne, 2016).

In mammals, activation of the hypothalamic-pituitary-adrenal (HPA) axis is a common

stress response, but this may vary depending on the nature of the stressor (Mason, 1971); it is important to consider this when assessing stress impacts. Changes in abiotic conditions, such as

157 in food availability, or the introduction of toxins or diseases can be stressful, but such changes do 
158 not arouse fear. However, a stress response involving peripheral autonomic and neuroendocrine

159 changes (Yates, Russell \& Maran, 1971; Sapolsky, Romero \& Munck, 2000; McEwen \&

160 Wingfield, 2003), can be initiated by fear arousal (LeDoux, 2003; LaBar \& LeDoux, 2011).

161 Animals with sophisticated nervous systems, such as mammals, exhibit a central motive state

162 between threat stimulus and response that is driven by the amygdala (Pitkanen, 2000) and can be

163 identified as 'fear' (Mineka, 1979; Öhman, 2000). Fear has been defined as a psychological state

164 that triggers physiological responses to avoid or escape from a stressor (Epstein, 1972; LeDoux,

165 1996). The development of successful defense mechanisms to fear-inducing stressors has clear

166 survival benefits for animals, and thus fear can be seen as a driver of evolutionary adaptations

167 (Tooby \& Cosmides, 1990). Common strategies of escape and avoidance allow animals to cope

168 with recurrent stressors, such as the fear-inducing threat of predation (Lima \& Dill, 1990).

The sections of the mammalian amygdala associated with fear behaviour serve as an interface between sensory input and information transport and processing, endocrine response, and motor output (Davis \& Whalen, 2001). These interactions are associated with learning and

172 memory via the involvement of the lateral and basal nuclei, as demonstrated on captive rodents 173 using neurotoxic lesions on the basal and lateral nuclei of the amygdala (e.g. Wallace \& Rosen, 174 2001), and are evident in Pavlovian fear conditioning paradigms (Davis, 1992; Maren, 2001). 175 Activation of hormones, specifically glucocorticoids and norepinephrine in stress responses initiated by fear arousal provides feedback to the brain that influences emotion control and 177 cognition, which contributes to fear conditioning (Rodrigues, LeDoux \& Sapolsky, 2009). Fear responses may, therefore, be both conditioned as aversive learnt behaviours (e.g. Fanselow \&

179 Poulos, 2005), and unconditioned as innate freezing responses (e.g. Schulkin, Thompson \& 180 Rosen, 2003). 

actions - quantifying glucocorticoid outputs from the autonomic nervous and HPA systems should yield a measurable indication of fear from predation as a stressor. Minimally invasive techniques are available that assay glucocorticoid levels in faeces, fur, or feathers (Sheriff et al., 2011; Cook, 2012; Palme, 2019). Using minimally invasive methods to measure glucocorticoid levels in the wild does not necessarily yield an isolated 'output' of a fear or predator/human187 induced stress response (Rosen \& Schulkin, 2004). This situation results from glucocorticoids not being a molecule of fear per se but having a fundamental role in maintaining energy balance (Rosen \& Schulkin, 2004). As such, glucocorticoids may change not just because of fear but also in response to other exogenous stressors, like food shortage (McEwen \& Wingfield, 2003).

Nevertheless, such methods could usefully compare longer-term stress responses among habitats or along disturbance gradients with variable exposure to predators, by following experimental designs that are considerate of additional stressors that may be present (see: MacDougallShackleton et al., 2019). challenges to an individual's physiological systems (Johnstone, Lill \& Reina, 2012; Brearley et al., 2013; Malcolm et al., 2014; Arlettaz et al., 2015; Geary et al., 2019; Legge et al., 2019). Interactive fear and stress effects are context-dependent (Belarde \& Railsback, 2016). They can be additive and combine the multiple impacts, synergistic whereby the presence of one threat amplifies another (Doherty et al., 2015), or antagonistic whereby one threat cancels the effects of the other. A reduction in the activity of mesopredators in the presence of humans provides an

202 example of antagonism (Clinchy et al., 2016). Additive, synergistic, and antagonistic reactions 
204 multiple stressors (Crain et al., 2008; Côté, Darling \& Brown, 2016; Gunderson et al., 2016;

205 Jackson et al., 2016; Geary et al., 2019; Legge et al., 2019).

206 Exposure to a stressor(s) that is prolonged, constant, or recurring can have chronic

207 impacts, as recovery from a stressor cannot occur whilst the threat remains (Sapolsky, Romero \&

208 Munck, 2000). Acute stress occurs as the initial response to a threat to sustain fitness in the short

209 term; it subsides once the responding action—be it freezing, fighting, or fleeing — diminishes the

210 threat (Wingfield \& Kitaysky, 2002). Activation of the HPA axis in an acute stress response has

211 rapid effects that increase immune system function, energise muscles via enhanced

212 cardiovascular tone, and heighten cognition, including memory (Sapolsky, Romero \& Munck,

213 2000). These responses occur via increased cerebral perfusion rates and use of glucose, all of

214 which come at the cost of decreased appetite and reproductive behaviours (Sapolsky, Romero \&

215 Munck, 2000). Effectively, the acute stress response suspends non-essential behaviours in favour

216 of altered behaviours that minimize the threat (Wingfield \& Kitaysky, 2002).

217 Continued exposure to a stressor, or stressors, creates a state of chronic stress, which is

218 classically described as allostatic overload (Dantzer et al., 2014). Allostatic load describes the

219 body's ability to maintain homeostasis in response to a stressor (Sterling \& Eyer, 1988; McEwen

220 \& Stellar, 1993; McEwen \& Wingfield, 2003). Allostatic overload, by extension, refers to the

221 inability to maintain homeostasis and thus an organism's increased susceptibility to external

222 stressors (Sterling \& Eyer, 1988; McEwen \& Stellar, 1993; McEwen \& Wingfield, 2003).

223 Chronic stress reduces an organism's resilience to future stressors by inducing extended

224 behavioural changes in feeding, fighting, and mating (Mineur et al., 2006). Chronic stress also

225 affects an organism's physiological state by suppressing or impairing the reproductive system

226 and decreasing physiological resistance to pathogens and toxins through the suppression of 
227 immune function (Dhabhar \& McEwen, 1999; McEwen \& Wingfield, 2003; Romero, 2004;

228 Travers et al., 2010; Feng et al., 2012). Repeated exposure to a stressor can have population and

229

230

231

232

233

234

235

236

237

238

239

240

241

242

243

244

245

246

247

248

249 community level consequences as homeostasis is compromised, and it increases susceptibility to additional stressors and can have flow-on effects. For example, chronic risk of predation, which facilitates changes in nutrient demand for prey species and thus changes in the elemental composition of their excreta, can alter nutrient cycling in the community and ecosystem (Hawlena \& Schmitz, 2010).

Cases of acclimatisation to chronic or repeated acute stressors have been observed, although the process often results in enhanced activation of the HPA axis to novel stressors, and thus may not be beneficial to fitness (Romero, 2004). Instead of acclimatising to a chronic or repeated stressor, glucocorticoid levels can remain the same, or become chronically elevated, or the HPA axis can shut down completely and render an animal vulnerable to future threats (Romero, 2004). Physiological impairment of the neurological, cardiovascular and musculoskeletal systems may also result from chronic stress: neurons of the brain can atrophy and impair memory, or grow and enhance fearfulness with extensive releases of adrenaline and cortisol (Roozendaal, 2000; McEwen, 2004); atherosclerotic plaques also may form and impede blood flow from repeated elevation of blood pressure (Manuck et al., 1988), and skeletal muscle can suffer severe protein loss (Wingfield \& Kitaysky, 2002).

Although chronic and acute stress responses have been well defined for mammals in laboratory studies, results from in situ studies show that reactions vary with the stressor type that animals are exposed to, as well as habituation potential, food availability, social interactions, and density (Dickens \& Romero, 2013). In situ mammalian endocrine responses to a consistent stressor, such as human activity, have not been studied sufficiently to be able to determine if

Peer) reviewing PDF | (2019:09:41203:3:0:NEW 9 Apr 2020) 
250 there is a particular pattern of response. Avian endocrine responses to such stressors have been

251 more extensively studied and they reveal that urban habitats, perceived as a consistent stressor,

252 can shape endocrine responses in birds. However, a consistent stress response pattern has yet to

253 be observed in birds (Bonier, 2012). Inconsistent behavioural responses of mammals and other

254 animals to human activities that are often observed can perhaps be linked to modulating factors

255 such as the level of human activity, the species and condition of the animal being observed, and

256 the spatio-temporal context (Tablado \& Jenni, 2017).

Mammalian behavioural responses to fear and stress: the landscape of fear concept

259

260

261

262

263

264

265

266

267

268

269

270

271

272

The landscape of fear concept (Laundré, Hernández \& Altendorf, 2001) postulates that prey are aware of microhabitat patches associated with high and low predation risk, where predators are either active and ubiquitous, or scarce (Laundré, Hernández \& Altendorf, 2001; Shrader et al., 2008; van der Merwe \& Brown, 2008; Laundré, Hernández \& Ripple, 2010). Theoretically, landscape of fear effects should increase with landscape heterogeneity, since the differences between high and low risk sites become more pronounced and prey can more easily avoid highrisk sites (Bleicher, 2017; Gaynor et al., 2019). However, this relationship can depend on the species and condition of the habitat and, for some species, simple habitats can be the safest (e.g. Hammerschlag, et al., 2015; Schmidt \& Kuijper, 2015; Atuo \& O'Connell, 2017). Landscape of fear effects will also be more pronounced in systems where interactions between predators and prey are less frequent (Schmitz, 2008), as is evident in findings from Pavlovian fear conditioning, and the 'risk allocation hypothesis' - which states that animals exposed to constant high predation risk will increase their foraging risks over time (Lima \& Bednekoff, 1999; Van Buskirk et al., 2002). Fear arousal in a landscape of fear results in two predictable outcomes: 
273 either avoidance of high risk areas, or modulation of behaviour (e.g. increased vigilance) to

274 reduce predation risk when foraging in such areas (Gaynor et al., 2019). These outcomes indicate

275 the potential positive benefits to conservation management of considering fear arousal and stress

276 levels, and the direct and indirect cues that may trigger these effects (Atkins et al., 2017).

The likelihood of survival of a prey species is improved by having a well-developed perception of high predation risk, as it allows adaptive behavioural responses to be established (Bókony et al., 2009). Habitat shifts, temporal shift, grouping, vigilance, and freeze, fly, and fight responses are the most studied such responses to the non-consumptive effects of predators (Say-Sallaz et al., 2019). These often develop due to increased interaction rates between predators and prey. However, chronic stress impacts that are sufficient to affect reproduction and long-term survival can be experienced by prey species perceiving recurring predation risks (Thomson et al., 2010; Clinchy et al., 2011). Chronic perceived predation risk may also result in altered foraging activity driven by fear. This can affect where and what prey eat (Schmitz, Krivan \& Ovadia, 2004), causing them to move from risky to sheltered microhabitats (Trussell, Ewanchuk \& Matassa, 2006), in turn altering the distribution and availability of resources. Fearbased adaptive behavioural responses such as these underlie the landscape of fear concept.

For mammals, fear arousal can be triggered both by a predator's presence or by a predator cue, such as an associated scent. Olfaction can be a key driver of fear arousal (Soso et al., 2014; Banks, Daly \& Bytheway, 2016; Jones et al., 2016; Parsons et al., 2017). The mechanics of this are best understood in mammals: odours are detected by the accessory olfactory bulb that transmits information directly to the amygdala and hypothalamus, where fight or flight responses are developed (Fogaca et al., 2012; Canteras, Pavesi \& Carobrez, 2015). 
296

297

298

299

300

301

302

303

304

305

306

307

308

309

310

311

312

313

314

315

316

317

mammals to predators or their cues to induce stress, and in doing so revealed that exposure to

predator cues alone can affect the neural circuitry associated with fear (Rosen \& Sculkin, 1998, 2004).

Subtle cues such as predator odours may precede threats and allow for a mammalian prey animal's fear state to be conditioned to a cue that occurs before, or in correlation with, a previously encountered predation threat (Rescorla \& Solomon, 1967; Rosen, 2004). Predation risk may, therefore, be perceived by prey species eavesdropping on predator scent marks, such as urine, faeces, or fur in the environment (Banks, Daly \& Bytheway, 2016; Jones et al., 2016).

Such odours have been observed experimentally to induce fear-like responses of freezing (Wallace \& Rosen, 2000), vigilance (Nersesian, Banks \& McArthur, 2012), fleeing (Anson \& Dickman, 2013), and avoidance (Hayes, Nahrung \& Wilson, 2006), across a wide range of species in both field and laboratory experiments (Apfelbach et al., 2005, 2015). Consequently, landscape of fear topography, where predators indirectly influence prey behaviour across a range of microhabitats, can arise from the influence of predator olfactory cues on mammalian prey foraging behaviours as much as it can from the direct threat of predation (e.g. Brown \& Kotler, 2004; Parsons \& Blumstein, 2010; Cremona, Crowther \& Webb, 2014; Mella, Banks \& McArthur, 2014; Hoffman, Sitvarin \& Rypstra, 2016). It is worth noting, however, that whilst predator olfactory cues can elicit a fear or stress response, they do not always do so (Apfelbach et al., 2005). This may be because predators often leave the site after depositing a cue, and the cue intensity diminishes. Predator cues elicit responses that are modulated according to the differential intensity of the perceived threat, prior experience, or pending further information gathering, and thus can be perceived as a low risk by prey (Bedoya-Pérez et al., 2019). 
budget, resulting in poor reproduction and health either via energy exhaustion from stress (i.e.

Iribarren \& Kotler, 2012, Smith et al., 2019) to identify, protect and extend safe foraging areas, could assist in the conservation of wildlife subject to human activity or multiple stressors such as human activity and predators.

Human activity can influence wildlife in a wide variety of ways (e.g. Albert \& Bowyer, 1991; Bowyer et al., 1999). Pressure from increased proximity to human activity or development that encroaches upon animal home ranges, result in wildlife becoming either: 1) 'urban avoiders' that move away from human activity; 2) 'urban adapters' that make some use of anthropogenic resources but still rely largely upon those found naturally; or 3) 'urban exploiters' that are synanthropic and make full use of anthropogenic resources (McKinney, 2006). The effects of 
341 human activity can therefore differ between species and trophic levels, and even within the same

342 species, depending on personality. Furthermore, the negative effects of a disturbance on one

343 species may result in flow-on responses of positive consequences for its prey, predators, or

344 competing species (e.g. Gill, Sutherland \& Watkinson, 1996; Crooks \& Soulé, 1999; Leighton,

345 Horrocks \& Kramer, 2010). These effects, however, depend strongly on the availability of

346 necessary resources within the human occupied / disturbed areas, and will often differ between

347 systems.

It has been postulated that humans may impose widespread effects on ecosystem function

349 if they induce greater fear responses in ubiquitous small predators than in top predators (Clinchy

350 et al., 2016), or by increasing physiological stress in large ungulates through antagonistic

351 behaviours (Vijayakrishnan et al., 2018). Indeed, human activity can be comparable to the

352 above-mentioned impacts of predation, creating landscapes of fear (Hofer \& East, 1998; Frid \&

353 Dill, 2002; Rehnus, Wehrle \& Palme, 2014; Patten \& Burger, 2018), and disrupting foraging

354 (Ciuti et al., 2012; Clinchy et al., 2016). Humans can also act as "super-predators" that

355 disproportionately kill carnivores and drive trophic cascades (Darimont et al., 2015). Trophic

356 cascades can also arise when human activity has non-consumptive effects on the ecological roles

357 of large predators (Smith et al., 2017). For example, large predators may increase their hunting

358 efforts in urban areas: if their own fear response to human activity results in less time spent

359 consuming a kill, this in turn may increase their kill rate of prey in urban areas to meet their

360 energy needs (Smith et al., 2017). When large predators avoid human activity, and / or meso-

361 predators reduce their foraging around human activity, prey species may respond by increasing

362 their own foraging activity (Suraci et al., 2019), effectively taking refuge behind the "human 
363 shield" that is reducing predation pressure for them (Berger, 2007; Leighton, Horrocks \&

364 Kramer, 2010; Kuijper et al., 2015).

Human activity can affect the trophic structure of communities not only via top-down pressure, but also by exerting bottom-up pressure through the constant provision of alternative resources (Fischer et al., 2012), such as subsidies of shelter, water and food with year-round primary production. These resources can outweigh the stresses of human disturbance and influence population and community behaviours (Parris, 2016), resulting in urban colonisation by wildlife (Shochat, Lerman \& Fernández-Juricic, 2010; Jokimäki, et al., 2011). As such, from the human shield and access to food, water or shelter subsidies (Lyons et al., 2017). It is possible that, given these conditions, and provided that resource subsidies are nutritionally rich and accessing them does not increase pathogen transmission risk (Murray et al., 2016), prey species like small mammals would experience fitness benefits in urban areas. Resource subsidies can also be exploited by predators, resulting in increased predator activity in urban areas but also in altered foraging behaviours that either decrease or increase predation on small prey (Iossa et al., 2010; Bateman \& Fleming, 2012; Fischer et al., 2012; Newsome et al., 2014, 2015). roads and vehicles, or of active interference from recreational activities conducted in designated conservation areas, can lead to physiological stress or displacement, countervailing any positive effects of humans on wildlife (Kloppers, St Clair \& Hurd, 2005; Banks \& Bryant, 2007; Berger, 
A common response in mammals to increased exposure to human activity is a temporal

387

388

389

390

391

392

393

394

395

396

397

398

399

400

401

402

403

404

405

406

407

408

shift in activity patterns, from diurnal to crepuscular or nocturnal, to avoid interaction with

humans (McClennen et al., 2001; Tigas, Van Vuren \& Sauvajot, 2002; Riley et al., 2003;

Ditchkoff, Saalfeld \& Gibson, 2006; Gaynor et al., 2018); the same or reverse may occur too, to reduce interactions with predators (Brown, 2000; Laundré, Hernández \& Altendorf, 2001; Kohl et al., 2018; Smith et al., 2019). Temporal shifts can have strongly negative effects if they limit a forager's ability to locate and capture prey (Ditchkoff, Saalfeld \& Gibson, 2006). Regardless of the response, it is evident that human activity can have profound indirect effects on community interactions through altering individual behaviour, particularly foraging, through either fear arousal or a stress response (e.g. Frid \& Dill, 2002; Werner \& Peacor, 2003).

The ability of wildlife to cope with urban environments can occur through either plastic or evolved shifts in behaviour, foraging, food preferences, or predator avoidance, and in shifts in the timing of breeding (Ditchkoff, Saalfeld \& Gibson, 2006; Møller, 2009; Shochat, Lerman \& Fernández-Juricic, 2010; Rodriguez, Hausberger \& Clergeau, 2010; Alberti, 2015; McDonnell \& Hahs, 2015; Otto, 2018; Santini et al., 2019). It is most common for urban-occupying species to plastically adjust to human imposed stressors (Donihue \& Lambert, 2015), with some ultimately evolving tolerance to urban environments. Human activity can therefore impose pressures that are strong enough to influence changes in behaviour and in physiology — endocrinology in particular (Bonier, 2012; Snell-Rood \& Wick, 2013; Otto, 2018). Bolder individuals are most likely to exploit novel opportunities and have reduced stress responses to human activity (Atwell et al., 2012). Animals that routinely encounter human activity, typically provide parental care, and are capable of reproducing multiple times across their life span may produce offspring that are acclimated to human activity and accordingly show lower fear/stress responses (Schell et al., 
409 2018). Habituation of groups of animals to human activity is being increasingly observed, often

410 as a result of bold individuals spending significant amounts of time around human-disturbed

411 areas and displaying reduced fear responses (Stillfried et al., 2017). This counters the idea that

412 human activity always imposes landscapes of fear, but may reflect the combination of reduced

413 resource availability and bold personalities that allow for urban habituation (Lowry, Lill \&

414 Wong, 2012). In some instances this may be problematic for humans if increased interactions

415 with habituated animals increase vehicle accidents and / or transfer of zoonotic diseases; this

416 highlights the potential need to manage some mammalian prey species in urban areas (Honda et 417 al., 2018).

418 Fear and acute/chronic stress may be constant hurdles faced by wildlife, but adding the 419 effects of anthropogenic disturbance could result in the elevation of acute stress responses to 420 prolonged and widespread chronic stress, and upscale the possible impacts from individuals to 421 populations (Rehnus, Wehrle \& Palme, 2014). As we have outlined, human activity can both 422 indirectly and directly create landscapes of fear, influencing and amplifying existing landscapes 423 of fear through interactive effects. Predator presence and human activity can also interact to alter 424 ecosystem structure and modify the predation risk perceived by prey species, with either positive 425 or negative impacts dependent upon the circumstances. The combination of stress resulting from 426 the pressures of altered predator-prey interactions and human activities is yet to be investigated 427 extensively. Understanding the cumulative effects that both may impose is critical for effective 428 conservation of wildlife in an increasingly human-influenced world. 
431 As we have illustrated, fear can produce stress and simultaneous multiple stressors can have

432 chronic effects that negatively influence both predator and prey species populations (Allan et al.,

433 2013). To synthesize these impacts, we note that in modern urban situations both habitat

434 stressors and introduced stressors now collide (Figure 1). Habitat stressors result from naturally

435 occurring environmental factors such as native predator presence (especially for prey), social and

436 reproductive pressures, limited access to refuges / nests resource, food and water, disease and

437 parasite prevalence, and produce predictive homeostasis responses by prey species (Figure 1).

438 Introduced stressors, by contrast, are additional stressors that are imposed by human actions that

439 result in reactive homeostasis responses. These introduced anthropogenic stressors include

440 structural developments that change landscapes, human recreational activities in natural habitats

441 (including use of vehicles), introduced pollutants and toxins that alter landscapes and resource

442 quality, and introduced predators and altered predator-prey interactions (Figure 1). The

443 combination of impacts from both naturally occurring and introduced anthropogenic stressors

444 has the potential to cause a cumulative stress response that can result in homeostatic overload or

445 failure, as defined by Romero, Dickens and Cyr (2009), and may result in population collapses

446 due to increased susceptibility of individuals to the additional stressors (as we have demonstrated

447 above, and Figure 1). Cumulative stress may be additive or synergistic, and is likely to be

448 particularly detrimental for prey species. For example, if prey species face multiple stressors,

449 they may take greater foraging risks, or be less able to allocate energy to vigilance or flight

450 behaviours, and thus become more susceptible to predation or additional stressors. In the case of

451 population-impacting stressors, the local population may be impacted to a high degree such that

452 it becomes threatened (e.g. Sweitzer, 1996; Doherty et al., 2015). As such, conservation action in 
453 areas where simultaneous introduced stressors occur in addition to natural ecosystem pressures,

454 like in urban and peri-urban habitats, may urgently needed.

455 The most direct way to alleviate stress in wildlife is to remove or reduce the key

456 stressors. This may be difficult if the stressors are anthropogenic, as the needs of the expanding

457 human population often usurp those of wildlife; alternative solutions then need to be considered.

458 A suite of activities related to managing vegetation structure, density, and/or heterogeneity may

459 well provide such an alternative solution. These activities result in increased availability of

460 potential refuge sites and may be readily achieved through ongoing habitat engineering that, for

461 example, supports the growth of structurally complex plants or adds logs / rock piles to reduce

462 areas of open space. In order to mitigate introduced fear and stress effects, it is important that

463 future studies investigate whether vegetation management and other habitat components can

464 alleviate some of the pressures associated with multiple introduced stressors for target species.

466 Managing habitat to alleviate wildlife fear and stress

467 The impact of predators (or human activity) can be mitigated by changing the configuration of

468 risky areas within a habitat (Hopcraft, Sinclair \& Packer, 2005; Lone et al., 2014). Food

469 availability often drives habitat selection (e.g. Sherman, 1984; Johnson \& Sherry, 2001), but

470 predation risk and human activity affect a suite of correlated factors such as movement decisions

471 (Turcotte \& Desrochers, 2003), foraging patterns (Gil, Zill \& Ponciano, 2017), social

472 organisation (Rodríguez, Andrén \& Jansson, 2001), and reproductive success (Zanette et al.,

473 2011). Supplementation of essential resources including refuges, nests or roosts, food, and water

474 to wildlife is a growing conservation method due to its ease of implementation, immediate 
475 results, and favourable portrayal in the media (Sergio et al., 2018). One example of positive

476 results includes increased parasite resistance in nestling birds after supplementation with high-

477 quality food during the stressful young-rearing stage (Knutie, 2020). Another example is the

478 reduction in impact from introduced predators on small desert mammals following the addition

479 of artificial refuge structures (Bleicher \& Dickman, 2020). Despite these successes, negative

480 impacts can also ensue following supplementation. Built-up refuges may be primarily

481 investigated by invasive species, such as the black rat (Rattus rattus), which could potentially

482 deter commensal native species and support the population growth of invasive species (Price \&

483 Banks, 2018). Artificial nests or roosts can support increased predation rates owing to the

484 structure supporting a sit-and-wait predator at the exit (e.g. McComb et al., 2019). Food and

485 water subsidies can increase pathogen transmission, reduce movement and migratory behaviours,

486 increase predator-prey interaction rates, and competitor aggression interactions (Murray et al.,

487 2016). However, owing to the benefits of supplementation, especially during times of stress, it

488 may be used as a tool to mitigate the negative impacts of stress on wildlife if conducted in a

489 targeted, monitored and well-considered manner (e.g. Freeman et al., 2020).

490

Considering the existing knowledge base on food and water supplementation, meta-

491

492

493

494

495

496

497

analyses have suggested that the associated disease risk may be managed by focusing on specific natural food sources and pathogen groups subject to the target ecosystem and by increasing the spatial extent of feeding stations across potential linked habitats, which also limits microparasite host aggregations (see: Becker, Streicker, \& Altizier, 2015; Becker et al., 2018). In considering the specific needs of target animals and ecosystems, chainsaw-carved cavities have more favourable thermodynamic properties for small mammals and birds than do artificial next boxes (Griffiths et al., 2018). As they mimic natural hollows they are also less likely to increase rates 
498 of predation. Supplementation projects are therefore moving forward using this growing

499 knowledge base to adaptively tailor methods to specific conditions, and to orchestrate pre- and

500 post-monitoring that ensures successful stress mitigation (Civitello et al., 2018).

501 Survivorship of prey, in the face of predation stressors, is often positively correlated with

502 increased structural complexity of the habitat (Hopcraft, Sinclair \& Packer, 2005; Lone et al.,

503 2014; Leahy et al., 2016). This has been demonstrated in many studies to be a consequence of

504 the increased opportunities for prey to escape and hide, thereby mediating predator-prey

505 dynamics by reducing encounter rates, as only a proportion of the total prey population remains

506 available to predators (e.g. Holt, 1984; Kotler \& Brown, 1988; Bianchi, Schellhorn \& Van Der

507 Werf, 2009; Rieucau, Vickery \& Doucet, 2009; Klecka \& Boukal, 2014; Laundré et al., 2014).

508 The extensive research on the benefits to prey of habitat structural complexity builds on the

509 'habitat heterogeneity hypothesis,' which postulates that structurally complex habitats support

510 increased species diversity by offering a wide range of niches and diverse ways of exploiting

511 resources (Bazzaz, 1975). Habitat complexity, by extension, has been generalized to be a

512 primary driver of biodiversity (Pianka, 2011). The landscape of fear concept accepts this

513 principle too, in that a wide range of microhabitat types offers multiple foraging and shelter

514 conditions with varied predation risks for species. For example, northern quolls (Dasyurus

515 hallucatus) of the semi-arid Pilbara region in Western Australia utilise complex rocky habitats in

516 preference to open grasslands where the threat of predation from feral cats (Felis catus) is greater

517 (Hernandez-Santin, Goldizen \& Fisher, 2016).

Animals in habitats with high predation pressure may display foraging preferences for

519 microhabitats or times that they perceive to be safe (Brown, 2000; Laundré, Hernández \&

520 Altendorf, 2001; Laundré, Hernández \& Ripple, 2010). Some small mammals seek structurally 
521 complex vegetation owing to the reduced risk of predation and increased reward of foraging they

522 find there (Lima \& Dill, 1990; Andruskiw et al., 2008). Others, such as the Australian hopping

523 mouse (Notomys alexis) that exhibit bursts of speed in open habitat, are less adept at moving

524 through complex vegetation (Spencer, Crowther \& Dickman, 2014). No matter the species, in

525 landscapes of fear a prey species' use of the topography, refuges, and escape substrates can

526 indicate its perceived risk of predation (Brown \& Kotler, 2004; van der Merwe \& Brown, 2008;

527 Shrader et al., 2008), and the associated fear and stress that may arise or be alleviated due to

528 habitat structure. The same principle should be relevant to reducing stress in proximity to human

529 activity, considering that prey responses to human activity and predators are similar.

530 Human activity and disturbance can quickly reduce habitat complexity (Western, 2001).

531 However, enhancing habitat complexity and heterogeneity is being incorporated increasingly

532 into restoration and management efforts, with some success (Brown, 2003; Bernhardt \& Palmer,

533 2007; Palmer, Menninger \& Bernhardt, 2010). To balance the needs of people and biodiversity,

534 local planning procedures are at times now incorporating green spaces and greening initiatives

535 into urban areas. As habitat complexity and diversity are of particular importance in supporting

536 biodiversity and population sustainability, it is important that habitat structure underpins the

537 engineering of wildlife habitats in urban and urban-adjacent areas (Threlfall et al., 2016). The

538 effectiveness of any management regime depends on recognising the direct and indirect impacts

539 that occur across sustainable ecosystems. Consequently, habitat complexity as a management

540 objective requires that urban landscapes are approached on a case by case basis, with full

541 assessment before the habitat is ecologically engineered (Tews et al., 2004). 
544 Cumulative stress maps of human activity and stressors that occur naturally in ecosystems have

545 allowed returns on restoration investments to be maximized by indicating key areas that will or

546 do need intervention to mitigate the effects of severe stress on wildlife, as opposed to

547 unsuccessful piecemeal management that focuses on one or two stressors broadly (Allan et al.,

548 2013). Physiological and behavioural stress in wildlife may be cost-effectively and

549 straightforwardly observed by comparing the outcomes of simultaneous measurements taken

550 across a disturbance gradient where multiple stressors are both abundant and low, using several

551 well-established methods. Specifically, assays of faecal/urine/fur/feather glucocorticoid

552 metabolites can provide insight into the level of physiological stress an animal is experiencing

553 under comparative circumstances (see Cook, 2012; Cooke et al., 2013; Sheriff et al., 2011;

554 Palme, 2019). Pairing such results for each location with those of giving-up density surveys

555 (Brown, 1988) that can also be filmed by infrared motion sensor cameras to observe foraging

556 behavioural responses (e.g. Leo, Reading \& Letnic, 2015), yields an understanding of both

557 physiological stress responses and foraging responses. Comparing these results may further

558 indicate if behavioural responses are changing to moderate physiological stress impacts (e.g.

559 Carlstead, Brown, \& Seidensticker, 1993; Carlstead, Brown, \& Strawn, 1993). Simultaneous

560 measurements of habitat quality that include vegetation cover, refuges, distance to food / water

561 source, and distance to disturbances (e.g. human activity or predator sighting based on

562 spotlighting or in-field camera traps) will build a dataset for spatial correlation analyses that can

563 geographically map the landscape of fear. Such measurements should also identify what factors

564 influence the landscape, such as by use of behavioural data (e.g. Willems \& Hill, 2009) and / or

565 giving-up density data (e.g. van der Merwe \& Brown, 2008). 
567 samples, could be overlaid and compared to these results also. Such spatially mapped results may

568 clarify important areas that are in need of protection or the habitat types that could be extended

569 to mitigate stress impacts. It is worth noting that several authors have emphasized that these

570 methods need to be used correctly to ensure that stress and habitat factors are linked (e.g.

571 McMahon et al., 2018; Bleicher, 2017; Bedoya-Perez et al., 2013; MacDougall-Shackleton et

572 al., 2019). For example, collection of fresh faecal samples of a target species along a gradient of

573 high to low human activity would allow glucocorticoid metabolites to be assayed, providing

574 insight into potential stress induced by human activity along the gradient (Rehnus, Wehrle \&

575 Palme, 2014). A similar approach could be used to assay stress perceived by prey species in

576 areas of high and low predator activity, and sex hormones also could be assayed to explore sex-

577 related effects of stress. By allowing pathways of fear and stress to be mapped, including sites

578 where stressors from predators and human activity occur simultaneously, such methods should

579 allow managers to reliably identify where best to intervene to preserve at-risk populations and

580 maintain community stability. We consider potential interventions in more detail below.

581 If cumulative stressors occur and are suspected to have detrimental effects on target

582 wildlife populations or communities, we suggest that a potentially powerful mitigation approach

583 could be developed based on Cumulative Effects Assessments (CEA). Devised in the 1990s amid

584 growing concerns that Environmental Impact Assessments (EIA) did not consider all the effects

585 of urban and peri-urban developments (Smit \& Spaling, 1995), CEAs have been advocated as an

586 effective tool for use by on-ground practitioners (Duinker et al., 2012). Numerous countries have

587 mandated that CEAs be incorporated into EIAs, namely: the United States of America, Canada,

588 Europe, New Zealand, and Australia each advocate some level of CEAs (Therivel \& Ross, 
589 2007). Despite this legal requirement, and the CEA concept being widely known in scientific

590 literature, it is rarely applied in practice (Ma, Becker \& Kilgore, 2009; Foley et al., 2017).

$591 \quad$ We propose further that the principles of the 'reactive scope model' be used to develop

592 CEAs, to identify where cumulative stressors occur, and thus better inform conservation

593 management initiatives in areas where wildlife is subject to homeostasis overload or failure

594 (Figure 2). The results from the above mentioned methods and / or other applicable established

595 methods may be used to answer our suggested CEA questions. The reactive scope model

596 (Romero, Dickens \& Cyr, 2009) provides useful insight into the range of physiological mediators

597 available in response to a stressor. It maps the homeostasis range of a given species in four

598 stages: 1) predictive - change occurs in response to routine environmental change, such as

599 seasons or day to night; 2) reactive - change occurs in response to an unpredictable change,

600 allowing survival via classic stress responses; 3) overload - consistent changes occur in response

601 to a stressor, and chronic stress impacts start to occur; and 4) failure - the species shows inability

602 to sustain homeostasis, and is very susceptible to additional stressors and death (Romero,

603 Dickens \& Cyr, 2009). If our proposed CEA approach (Figure 2), based on the reactive scope

604 model, were applied to small mammals in urban, urban adjacent, and peri-urban ecosystems, for

605 example, then areas of conservation concern could be identified where the additive or synergistic

606 impacts of human disturbance and introduced predators combine with stressors that occur

607 naturally. Appropriate management, such as increasing habitat complexity or reducing human

608 activity in conservation areas (e.g. Bleicher \& Dickman 2020), could then be implemented to

609 alleviate these stressors.

610 
611 Fear and stressing in small mammal ecology in Australia; the need to consider the twin

\section{2 stressors of introduced predators and people in wildlife management}

613 Small mammals are often somewhat resilient to threatening processes owing to their high

614 population growth rates (Cardillo et al., 2005, 2006). However, in Australia small mammal

615 populations are declining quickly, and due to causes dissimilar to those driving global declines

616 (Woinarski et al. 2015). Declines in Australia have been attributed to a wide range of habitat

617 stressors: habitat loss, altered fire regimes, disease, increasing temperatures, decreasing water

618 availability, depleted soil quality, and salinity (Woinarski et al., 2015). However, mammals

619 within a 'critical weight range' (CWR: 35 to $5550 \mathrm{~g}$ ) are particularly vulnerable (Chisholm \&

620 Taylor, 2007; Woinarski, Burbidge \& Harrison, 2015) owing to the effects of predation by two

621 introduced carnivores, the red fox (Vulpes vulpes) and domestic house cat (Felis catus) that

622 arrived in Australia over 150 years ago (Johnson, 2006). If predators are introduced, their

623 impacts on prey are likely to be exacerbated owing to prey naïveté (Doherty et al., 2016). Such

624 impacts have been particularly acute on wildlife in Australia, where eutherian carnivores are

625 recent arrivals (Salo et al., 2007). However, the question of Australian native animal stress

626 responses and the extent of their naiveté to these introduced eutherian predators is debatable (see:

627 Banks \& Dickman, 2007; Carthey \& Banks, 2016). Although CWR mammals are of high

628 conservation concern, predation from introduced predators poses a threat also to all native

629 predators by reducing their food resources, which in turn may increase predation and predation-

630 associated stress on alternative food sources such as smaller $(<35 \mathrm{~g})$ or larger $(>5550 \mathrm{~g})$

631 mammal species. For example, a study examining the diet of a nocturnal, avian predator, the

632 sooty owl (Tyto tenebricosa) before and after red fox introduction, revealed a dietary shift post

633 introduction, with owls consuming more arboreal than terrestrial prey species after fox arrival 
634 (Bilney, Cooke \& White, 2006). This shift to consuming arboreal prey increased dietary overlap

635 with the sympatric powerful owl (Ninox strenua), providing disproportionate predation pressure 636 on prey in the ecosystems of East Gippsland, Victoria. Predation by red foxes and cats is prevalent not only in natural habitats but also in agricultural and urban habitats (Dickman, 1996; Morgan et al., 2009; Bino et al., 2010). The paths and roads that fragment urban and agricultural habitats are used frequently by these predators, which exacerbates their predation pressure on prey species by combining with impacts imposed by human activities (Latham et al., 2011, Červinka et al., 2013). Consequently, this can result in increased abundances of red foxes and cats in human-modified landscapes that border or include natural habitats (Towerton et al., 2011; Graham, Maron \& McAlpine, 2012). Urban and agricultural habitats present many threats to wildlife, but they may also offer food and shelter opportunities (Pickett et al., 2001; Gaston et al., 2005; Hobbs, Higgs \& Harris, 2009). As reported by Ives et al. (2016), 46 percent of threatened Australian animals occur in or near Australian cities. Thus, the fate of many species could depend on accommodating their needs in urban and agricultural habitats (Ives et al., 2016). A recent assessment of data collected at the Wildlife Rehabilitation Centre in Queensland Zoo, Australia, revealed that pet cat or dog attack, car strike, and entanglement in human-placed objects represented $56.4 \%$ of the causes of submission of injured wildlife; mortality rates associated with these traumas were also high, with $61.3 \%$ of admitted animals dying from their injuries (Taylor-Brown et al., 2019). These threats may contribute to landscapes of fear, through fear arousal, altered foraging behaviour, posttraumatic stress reactions, and cumulative stress exposures resulting in chronic stress responses. conservation planning continues to exclude urban and agricultural habitats from consideration 
657 (Dales, 2011). There is recognition of the scope of this issue in Australia (e.g. Hill et al., 2007;

658 Carthey \& Banks, 2012; Threlfall, Law \& Banks, 2012; McCauley et al., 2013; Banks \& Smith,

659 2015; Ives et al., 2016), but few studies have explored the interactive effects of introduced

660 predators and human activity on the survival of prey species. Despite the development of

661 glucocorticoid analysis techniques to determine stress in animals dating to the 1960s (Jones et

662 al., 1964), only six of the 60 extant small mammals of conservation concern in Australia have

663 been subject to studies seeking to better understand their glucocorticoid response to stressors

664 (Hing et al., 2014), such as predation by introduced species or human activity.

665

There is a need for alternative management regimes to mitigate the additional stressors of

666

human-imposed impacts on wildlife, and the situation we have outlined in Australia underlines

667 the urgency of this need. As there are difficulties with the current control of introduced predators

668 in Australia (Glen \& Dickman, 2005; Rayner et al., 2007; Bergstrom et al., 2009; Norton, 2009;

669 Warburton \& Norton, 2009; Carroll, 2011; Newsome et al., 2017), there is also an urgent need

670 for alternative management regimes to mitigate the additional stressors of introduced predator-

671 imposed impacts. As we have argued throughout this review, it is logical that biodiversity

672 conservation managers consider stress from the combined impacts of introduced predators,

673 altered predator interactions, human activity, and stressors that occur naturally in ecosystems.

674 Using the example methods to conduct our proposed CEA, based on the reactive scope model, to

675 draft appropriate management plans, such as increasing habitat complexity or reducing human

676 interaction in areas, would be a progressive response towards preserving many species of

677 Australian small mammals and their constituent communities.

678

679 Conclusion

Peer] reviewing PDF | (2019:09:41203:3:0:NEW 9 Apr 2020) 
680 Considering ongoing global urbanization and the acknowledged importance of urban areas to 681 biodiversity conservation, there is a great need for increased focus on the management of urban 682 biodiversity. Management decisions require information about fear and stress impacts on 683 wildlife, including impacts from both human activities and predators, especially if they are novel 684 or introduced. Understanding the impacts of human activities is a research priority for modern 685 science. There are many gaps in our current understanding of fear and stress impacts on wildlife, 686 and of associated impacts of altered predation pressures and the persistence of target populations.

687 To sustain biodiversity in urban and urban-adjacent green space habitats, reserves and 688 conservation areas, it is vital that we establish better understanding and management of the 689 multiple stressors that operate in these systems.

\section{References}

692

693

694

695

696

697

698

699

700

701

702

703

704

705

706

707

Albert DM, Bowyer RT. 1991. Factors related to grizzly bear: human interactions in Denali National Park. Wildlife Society Bulletin (1973-2006), 19(3): 339-349.

Alberti M. 2015. Eco-evolutionary dynamics in an urbanizing planet. Trends in Ecology \& Evolution, 30(2): 114-126.

Allan JD, McIntyre PB, Smith SD, Halpern BS, Boyer GL, Buchsbaum A, Burton Jr. GA, Campbell LM, Chadderton WL, Ciborowski JJH, Doran PJ, Eder T, Infante DM, Johnson LB, Joseph CA, Marino AL, Prusevich A, Read JG, Rose JB, Rutherford ES, Sowa SP, Steinman AD. 2013. Joint analysis of stressors and ecosystem services to enhance restoration effectiveness. Proceedings of the National Academy of Sciences USA, 110(1): 372-377.

Andruskiw M, Fryxell JM, Thompson ID, Baker JA. 2008. Habitat-mediated variation in predation risk by the American marten. Ecology, 89(8): 2273-2280.

Anson JR, Dickman CR. 2013. Behavioral responses of native prey to disparate predators: naivité and predator recognition. Oecologia, 17: 367-377. DOI: 10.1007/s00442-012-2424-7.

Apfelbach R, Blanchard CD, Blanchard RJ, Hayes RA, McGregor IS. 2005. The effects of predator odors in mammalian prey species: a review of field and laboratory studies. Neuroscience \& Biobehavioral Reviews, 29(8): 1123-1144. 
Apfelbach, R., Parsons MH, Soini HA, Novotny MV. 2015. Are single odorous components of a predator sufficient to elicit defensive behaviors in prey species?. Frontiers in Neuroscience, 9: 263.

Arlettaz R, Nusslé S, Baltic M, Vogel P, Palme R, Jenni-Eiermann S, Pathey P, Genoud M. 2015. Disturbance of wildlife by outdoor winter recreation: allostatic stress response and altered activity-energy budgets. Ecological Applications, 25(5): 1197-1212.

Atkins A, Redpath SM, Little RM, Amar A. 2017. Experimentally manipulating the landscape of fear to manage problem animals. The Journal of Wildlife Management, 81(4): 610-616.

\section{Atwell JW, Cardoso GC, Whittaker DJ, Campbell-Nelson S, Robertson KW, Ketterson}

ED. 2012. Boldness behavior and stress physiology in a novel urban environment suggest rapid correlated evolutionary adaptation. Behavioral Ecology, 23(5): 960-969.

Atuo FA, O'Connell TJ. 2017. The landscape of fear as an emergent property of heterogeneity: Contrasting patterns of predation risk in grassland ecosystems. Ecology and Evolution, 7(13): 4782-4793.

Ayal Y. 2007. Trophic structure and the role of predation in shaping hot desert communities. Journal of Arid Environments, 68(2): 171-187.

Banks PB, Bryant JV. 2007. Four-legged friend or foe? Dog walking displaces native birds from natural areas. Biology Letters, 3: 611-613.

Banks PB, Dickman CR. 2007. Alien predation and the effects of multiple levels of prey naiveté. Trends in Ecology and Evolution, 22(5): 229-230.

Banks PB, Smith HM. 2015. The ecological impacts of commensal species: black rats, Rattus rattus, at the urban-bushland interface. Wildlife Research, 42(2): 86-97.

Banks PB, Daly A, Bytheway JP. 2016. Predator odours attract other predators, creating an olfactory web of information. Biology Letters, 12(5): 20151053.

Bateman PW, Fleming PA. 2012. Big city life: carnivores in urban environments. Journal of Zoology, 287(1): 1-23.

Bazzaz FA. 1975. Plant species diversity in old-field successional ecosystems in southern Illinois. Ecology, 56(2): 485-488.

Becker DJ, Streicker DG, Altizer S. 2015. Linking anthropogenic resources to wildlifepathogen dynamics: a review and meta-analysis. Ecology Letters, 18(5): 483-495.

Becker DJ, Snedden CE, Altizer S, Hall RJ. 2018. Host dispersal responses to resource supplementation determine pathogen spread in wildlife metapopulations. The American Naturalist, 192(4): 503-517. 
741

742

743

744

745

746

747

748

749

750

751

752

753

754

755

756

757

758

759

760

761

762

763

764

765

766

767

768

769

770

771

772

773

Bedoya-Perez MA, Carthey AJR, Mella VSA, McArthur C, Banks PB. 2013. A practical guide to avoid giving up on giving-up densities, Behavioural Ecology and Sociobiology, 67(10): 1541-1553.

Bedoya-Pérez MA, Smith KL, Kevin RC, Luo JL, Crowther MS, McGregor IS. 2019. Parameters that affect fear responses in rodents and how to use them for management. Frontiers in Ecology and Evolution, 7: 136. DOI: 10.3389/fevo.2019.00136.

Belarde TA, Railsback SF. 2016. New predictions from old theory: emergent effects of multiple stressors in a model of piscivorous fish. Ecological Modelling, 326: 54-62.

Bernhardt ES, Palmer MA. 2007. Restoring streams in an urbanizing world. Freshwater Biology, 52(4): 738-751.

Berger J. 2007. Fear, human shields and the redistribution of prey and predators in protected areas. Biology Letters, 3(6): 620-623.

Bergstrom DM, Lucieer A, Kiefer K, Wasley J, Belbin L, Pedersen TK, Chown SL. 2009. Management implications of the Macquarie Island trophic cascade revisited: a reply to Dowding et al. (2009). Journal of Applied Ecology, 46(5): 1133-1136.

Bianchi FJJ, Schellhorn NA, Van Der Werf W. 2009. Foraging behaviour of predators in heterogeneous landscapes: the role of perceptual ability and diet breadth. Oikos, 118(9): 13631372.

Bilney RJ, Cooke R, White J. 2006. Change in the diet of sooty owls (Tyto tenebricosa) since European settlement: from terrestrial to arboreal prey and increased overlap with powerful owls. Wildlife Research, 33(1): 17-24.

Bino G, Dolev A, Yosha D, Guter A, King R, Saltz D, Kark S. 2010. Abrupt spatial and numerical responses of overabundant foxes to reduction in anthropogenic resources. Journal of Applied Ecology, 47(6): 1262-1271.

Bleicher SS. 2017. The landscape of fear conceptual framework: definition and review of current applications and misuses. PeerJ, 5: e3772.

Bleicher SS, Dickman CR. 2020. On the landscape of fear: shelters affect foraging by dunnarts (Marsupialia, Sminthopsis spp.) in a sandridge desert environment. Journal of Mammalogy, 101(1): 281-290.

Bonier F. 2012. Hormones in the city: endocrine ecology of urban birds. Hormones and Behaviour, 61(5): 763-772.

Boonstra R, Hik D, Singleton GR, Tinnikov A. 1998. The impact of predator-induced stress on the snowshoe hare cycle. Ecological Monographs, 68(3): 371-394. 
774

775

776

777

778

779

780

781

782

783

784

785

786

787

788

789

790

791

792

793

794

795

796

797

798

799

800

801

802

803

804

805

806

Bókony V, Lendvai AZ, Liker A, Angelier F, Wingfield JC, Chastel O. 2009. Stress response and the value of reproduction: are birds prudent parents? The American Naturalist, 173(5): 589598.

Bonier F. 2012. Hormones in the city: endocrine ecology of urban birds. Hormones and Behavior, 61(5): 763-772.

Bowyer RT, Van Ballenberghe V, Kie JG, Maier JA. 1999. Birth-site selection by Alaskan moose: maternal strategies for coping with a risky environment. Journal of Mammalogy, 80(4): 1070-1083.

Brearley G, Rhodes J, Bradley A, Baxter G, Seabrook L, Lunney D, ... McAlpine C. 2013. Wildlife disease prevalence in human-modified landscapes. Biological Reviews, 88(2): 427-442.

Brown JS. 1988. Patch use as an indicator of habitat preference, predation risk, and competition. Behavioral Ecology and Sociobiology, 22(1): 37-47.

Brown JS. 2000. Foraging ecology of animals in response to heterogeneous environments. The ecological consequences of environmental heterogeneity. Blackwell, Oxford, UK. 181-214.

Brown BL. 2003. Spatial heterogeneity reduces temporal variability in stream insect communities. Ecology Letters, 6(4): 316-325.

Brown JS, Kotler BP. 2004. Hazardous duty pay and the foraging cost of predation. Ecology Letters, 7(10): 999-1014.

Cannon WB. 1932. The wisdom of the body, W. W. Norton and Company, New York, 177-201.

Canteras NS, Pavesi E, Carobrez AP. 2015. Olfactory instruction for fear: neural system analysis. Frontiers in Neuroscience, 9: 276 (https://doi.org/10.3389/fnins.2015.00276).

Cardillo M, Mace GM, Jones KE, Bielby J, Bininda-Emonds OR, Sechrest W, Orme CDL, Purvis A. 2005. Multiple causes of high extinction risk in large mammal species. Science, 309(5738): 1239-1241.

Cardillo M, Mace GM, Gittleman, JL, Purvis A. 2006. Latent extinction risk and the future battlegrounds of mammal conservation. Proceedings of the National Academy of Sciences of the United States of America, 103(11): 4157-4161.

Carlstead K, Brown JL, Seidensticker J. 1993. Behavioral and adrenocortical responses to environmental changes in leopard cats (Felis bengalensis). Zoo Biology, 12(4): 321-331.

Carlstead K, Brown JL, Strawn W. 1993. Behavioral and physiological correlates of stress in laboratory cats. Applied Animal Behaviour Science, 38(2): 143-158.

Carroll SP. 2011. Conciliation biology: the eco-evolutionary management of permanently invaded biotic systems. Evolutionary Applications, 4(2): 184-199. 
807 Carthey AJ, Banks PB. 2012. When does an alien become a native species? A vulnerable native 808 mammal recognises and responds to its long-term alien predator. PLoS ONE, 7(2): e31804.

809 Carthey AJR, Banks PB. 2016. Naiveté is not forever: responses of a vulnerable native rodent 810 to its long term alien predators, Oikos, 125(7): 918-926.

811 Carthey JR, Blumstein DT. 2018. Predicting predator recognition in a changing world. Trends 812 in Ecology and Evolution, 33(2): 106-115.

813 Červinka J, Šálek M, Padyšáková E, Šmilauer P. 2013. The effects of local and landscape814 scale habitat characteristics and prey availability on corridor use by carnivores: a comparison of 815 two contrasting farmlands. Journal for Nature Conservation, 21(2): 105-113.

816 Chisholm R, Taylor R. 2007. Null-hypothesis significance testing and the Critical Weight

817 Range for Australian mammals. Conservation Biology, 21(6): 1641-1645.

818 Ciuti S, Northrup JM, Muhly TB, Simi S, Musiani M, Pitt JA, Boyce MS. 2012. Effects of 819 humans on behaviour of wildlife exceed those of natural predators in a landscape of fear, PLoS 820 ONE, 7(11): e50611. https://doi.org/10.1371/journal.pone.0050611.

Civitello DJ, Allman BE, Morozumi C, Rohr JR. 2018. Assessing the direct and indirect effects of food provisioning and nutrient enrichment on wildlife infectious disease dynamics. Philosophical Transactions of the Royal Society B: Biological Sciences, 373(1745): p.20170101.

826

Clinchy M, Zanette L, Boonstra R, Wingfield JC, Smith JN. 2004. Balancing food and predator pressure induces chronic stress in songbirds. Proceedings of the Royal Society of London B: Biological Sciences, 271(1556): 2473-2479. 2011. Multiple measures elucidate glucocorticoid responses to environmental variation in predation threat. Oecologia, 166(3): 607-614.

Clinchy M, Zanette LY, Roberts D, Suraci JP, Buesching CD, Newman C, Macdonald DW. 2016. Fear of the human "super predator" far exceeds the fear of large carnivores in a model mesocarnivore. Behavioral Ecology, 27(6): 1826-1832.

Cook NJ. 2012. Minimally invasive sampling media and the measurement of corticosteroids as biomarkers of stress in animals. Canadian Journal of Animal Science, 92(3): 227-259. What is conservation physiology? Perspectives on an increasingly integrated and essential science. Conservation Physiology, 1(1): $\cot 001$. 20152592. 
842 Crain CM, Kroeker K, Halpern BS. 2008. Interactive and cumulative effects of multiple 843 human stressors in marine systems. Ecology Letters, 11(12): 1304-1315.

844 Cremona T, Crowther MS, Webb JK. 2014. Variation of prey responses to cues from a 845 mesopredator and an apex predator. Austral Ecology, 39(7): 749-754.

846 Crocker DE, Khudyakov JI, Champagne CD. 2016. Oxidative stress in northern elephant 847 seals: Integration of omics approaches with ecological and experimental studies. Comparative 848 Biochemistry and Physiology Part A: Molecular \& Integrative Physiology, 200: 94-103.

849 Crooks KR, Soulé ME. 1999. Mesopredator release and avifaunal extinctions in a fragmented 850 system. Nature, 400(6744): 563.

851 Dales JT. 2011. Death by a thousand cuts: incorporating cumulative effects in Australia's 852 Environment Protection and Biodiversity Conservation Act. Pacific Rim Law \& Policy Journal, 853 20: 149 - 178.

854 Dantzer B, Fletcher QE, Boonstra R, Sheriff MJ. 2014. Measures of physiological stress: a 855 transparent or opaque window into the status, management and conservation of species?, 856 Conservation Physiology, 2(1): cou023.

857 Darimont CT, Fox CH, Bryan HM, Reimchen TE. 2015. The unique ecology of human 858 predators. Science, 349(6250): 858-860.

859 Davis M. 1992. The role of the amygdala in fear and anxiety. Annual Review of 860 Neuroscience, 15(1): 353-375.

861 Davis M, Whalen PJ. 2001. The amygdala: vigilance and emotion. Molecular Psychiatry, 6(1): 862 13-34.

Dhabhar FS, McEwen BS. 1999. Enhancing versus suppressive effects of stress hormones on skin immune function. Proceedings of the National Academy of Sciences USA, 96(3): 10598651064.

Dickens MJ, Romero ML. 2013. A consensus endocrine profile for chronically stressed wild animals does not exist. General and Comparative Endocrinology, 191: 177-189.

Dickman CR. 1996. Impact of exotic generalist predators on the native fauna of Australia. Wildlife Biology, 2(3): 185-195.

870 Ditchkoff SS, Saalfeld ST, Gibson CJ. 2006. Animal behavior in urban ecosystems: modifications due to human-induced stress. Urban Ecosystems, 9(1): 5-12.

Doherty TS, Dickman CR, Nimmo DG, Ritchie EG. 2015. Multiple threats, or multiplying the 873 threats? Interactions between invasive predators and other ecological disturbances. Biological 874 Conservation, 190: 60-68. 
875

876

877

878

879

880

881

882

883

884

885

886

887

888

889

890

891

892

893

894

895

896

897

898

899

900

901

902

903

904

905

906

907

908

909

Doherty TS, Glen AS, Nimmo DG, Ritchie EG, Dickman CR. 2016. Invasive predators and global biodiversity loss. Proceedings of the National Academy of Sciences USA, 113(40): 1126111265.

Doherty TS, Dickman CR, Glen AS, Newsome TM, Nimmo DG, Ritchie EG, Vanak AT, Wirsing AJ. 2017. The global impacts of domestic dogs on threatened vertebrates. Biological Conservation, 210: 56-59.

Donihue CM, Lambert MR. 2015. Adaptive evolution in urban ecosystems. Ambio, 44(3): 194203.

Duinker PN, Burbidge EL, Boardley SR, Greig LA. 2012. Scientific dimensions of cumulative effects assessment: toward improvements in guidance for practice. Environmental Reviews, 21(1): 40-52.

Estes JA, Terborgh J, Brashares JS, Power ME, Berger J, Bond WJ, Carpenter SR, Essington TE, Holt RD, Jackson JBC, Marquis RJ, Oksanen L, Oksanen T, Paine RT, Pikitch EK, Ripple WJ, Sandin SA, Scheffer M, Schoener TW, Shurin JB, Sinclair ARE, Soulé ME, Virtanen R, Wardle DA. 2011. Trophic downgrading of planet Earth. Science, 333(6040): 301-306.

Epstein S. 1972. The nature of anxiety with emphasis upon its relationship to expectancy. Anxiety; Current Trends in Theory and Research, 291-337.

Fanselow MS, Poulos AM. 2005. The neuroscience of mammalian associative learning. Annual Review of Psychology, 56: 207-234.

Feng SF, Shi TY, Wang WN, Chen YC, Tan QR. 2012. Long-lasting effects of chronic rTMS to treat chronic rodent model of depression. Behavioural Brain Research, 232(1): 245-251.

Fischer JD, Cleeton SH, Lyons TP, Miller JR. 2012. Urbanization and the predation paradox: the role of trophic dynamics in structuring vertebrate communities. Bioscience, 62(9): 809-818.

Fleming PA, Bateman PW. 2018. Novel predation opportunities in anthropogenic landscapes. Animal Behaviour, 138: 145-155.

Fogaca MV, Lisboa SF, Aguiar DC, Moreira FA, Gomes FV, Casarotto PC, Guimaraes FS. 2012. Fine-tuning of defensive behaviors in the dorsal periaqueductal gray by atypical neurotransmitters. Brazilian Journal of Medical and Biological Research, 45: 357-365.

Foley MM, Mease LA, Martone RG, Prahler EE, Morrison TH, Murray CC, Wojcik D. 2017. The challenges and opportunities in cumulative effects assessment. Environmental Impact Assessment Review, 62: 122-134.

Freeman NE, Norris DR, Sutton AO, Newman AE. 2020. Raising young with limited resources: supplementation improves body condition and advances fledging of Canada jays. Ecology, 101(1): p.e02909. 
910 Frid A, Dill L. 2002. Human-caused disturbance stimuli as a form of predation

911 risk. Conservation Ecology, 6(1):11.

912 Gaston KJ, Warren PH, Thompson K, Smith RM. 2005. Urban domestic gardens (IV): the

913 extent of the resource and its associated features. Biodiversity and Conservation, 14(14): 3327 -

9143349.

915 Gaynor KM, Hojnowski CE, Carter NH, Brashares JS. 2018. The influence of human

916 disturbance on wildlife nocturnality. Science, 360:1232-1235. DOI: 10.1126/science.aar7121.

917 Gaynor KM, Brown JS, Middleton AD, Power ME, Brashares, JS. 2019. Landscapes of fear: 918 spatial patterns of risk perception and response. Trends in Ecology \& Evolution, 34(4): 355-368.

919 Geary WL, Nimmo DG, Doherty TS, Ritchie EG, Tulloch AI. 2019. Threat webs: reframing

920 the co-occurrence and interactions of threats to biodiversity. Journal of Applied Ecology, 56:

921 1992-1997.

922 Gil MA, Zill J, Ponciano JM. 2017. Context-dependent landscape of fear: algal density elicits 923 risky herbivory in a coral reef. Ecology, 98(2): 534-544.

924 Gill JA, Sutherland WJ, Watkinson AR. 1996. A method to quantify the effects of human

925 disturbance on animal populations. Journal of Applied Ecology, 33(4): 786-792.

926 Glen AS, Dickman CR. 2005. Complex interactions among mammalian carnivores in Australia, 927 and their implications for wildlife management. Biological Reviews, 80(3): 387-401.

928 Graham CA, Maron M, McAlpine CA. 2013. Influence of landscape structure on invasive 929 predators: feral cats and red foxes in the brigalow landscapes, Queensland, Australia. Wildlife 930 Research, 39(8): 661-676.

931 Griffiths SR, Lentini PE, Semmens K, Watson SJ, Lumsden LF, Robert KA. 2018.

932 Chainsaw-carved cavities better mimic the thermal properties of natural tree hollows than nest 933 boxes and log hollows. Forests, 9(5): 235.

934 Guiden PW, Bartel SL, Byer NW, Shipley AA, Orrock JL. 2019. Predator-prey interactions 935 in the Anthropocene: reconciling multiple aspects of novelty. Trends in Ecology and Evolution, 936 34(7):616-627.

937 Gunderson AR, Armstrong EJ, Stillman JH. 2016. Multiple stressors in a changing world: the 938 need for an improved perspective on physiological responses to the dynamic marine 939 environment. Annual Review of Marine Science, 8: 357-378.

940 Hammerschlag N, Broderick AC, Coker JW, Coyne MS, Dodd M, Frick MG, Godfrey MH, 941 Godley BJ, Griffin DB, Hartog K, Murphy SR. 2015. Evaluating the landscape of fear 942 between apex predatory sharks and mobile sea turtles across a large dynamic seascape. Ecology, 943 96(8): 2117-2126. 
944 Hawlena D, Schmitz OJ. 2010. Physiological stress as a fundamental mechanism linking

945

946

947

948

949

950

951

952

953

954

955

956

957

958

959

960

961

962

963

964

965

966

967

968

969

970

971

972

973

974

975

976

977 predation to ecosystem functioning. The American Naturalist, 176:537-556. DOI: $10.1086 / 656495$.

Hawlena D, Strickland MS, Bradford MA, Schmitz OJ. 2012. Fear of predation slows litter decomposition. Science, 336:1434-1438. DOI 10.1126/science.1220097.

Hayes RA, Nahrung HF, Wilson JC. 2006. The response of native Australian rodents to predator odours varies seasonally: a by-product of life history variation? Animal Behaviour, 71(6): 1307-1314.

Hill NJ, Carbery KA, Deane EM. 2007. Human-possum conflict in urban Sydney, Australia: public perceptions and implications for species management. Human Dimensions of Wildlife, 12(2): 101-113.

Hing S, Narayan E, Thompson RA, Godfrey S. 2014. A review of factors influencing the stress response in Australian marsupials. Conservation Physiology, 2(1): cou027.

Hobbie SE, Finlay JC, Janke BD, Nidzgorski DA, Millet DB, Baker LA. 2017. Contrasting nitrogen and phosphorus budgets in urban watersheds and implications for managing urban water pollution. Proceedings of the National Academy of Sciences USA, 114(16): 4177-4182.

Hobbs RJ, Higgs E, Harris J A. 2009. Novel ecosystems: implications for conservation and restoration. Trends in Ecology and Evolution, 24(11): 599-605.

Hofer H, and East ML. 1998. Biological conservation and stress. Advances in the Study of Behavior, 27: 405-525.

Hoffman CR, Sitvarin MI, and Rypstra AL. 2016. Information from familiar and related conspecifics affects foraging in a solitary wolf spider. Oecologia, 181(2): 359-367.

Holt RD. 1984. Spatial heterogeneity, indirect interactions, and the coexistence of prey species. The American Naturalist, 124(3): 377-406.

Honda T, lijima H, Tsuboi J, Uchida K. 2018. A review of urban wildlife management from the animal personality perspective: The case of urban deer. Science of the Total Environment, 644: 576-582.

Hopcraft JGC, Sinclair ARE, Packer C. 2005. Planning for success: Serengeti lions seek prey accessibility rather than abundance. Journal of Animal Ecology, 74(3): 559-566.

Iossa G, Soulsbury CD, Baker PJ, Harris S. 2010. A taxonomic analysis of urban carnivore ecology. In: Gehrt SD, Riley SPD, Cypher BL (eds) Urban Carnivores: Ecology, Conflict, and Conservation: 173-180. Johns Hopkins University Press, Baltimore, Maryland, USA.

Iribarren C, Kotler BP. 2012. Foraging patterns of habitat use reveal landscape of fear of Nubian ibex Capra nubiana. Wildlife Biology, 18(2): 194-202. 
978

979

980

981

982

983

984

985

986

987

988

989

990

991

992

993

994

995

996

997

998

999

1000

1001

1002

1003

1004

1005

1006

1007

1008

1009

Ives CD, Lentini PE, Threlfall CG, Ikin K, Shanahan DF, Garrard GE, Bekessy SA, Fuller RA, Mumaw L, Rayner L, Rowe R, Valentine LE, Kendal D. 2016. Cities are hotspots for threatened species. Global Ecology and Biogeography, 25(1): 117-126.

Jaatinen K, Seltmann MW, Öst M. 2014. Context-dependent stress responses and their connections to fitness in a landscape of fear. Journal of Zoology, 294(3): 147-153.

Jackson MC, Loewen CJG, Vinebrooke RD, Chimimba CT. 2016. Net effects of multiple stressors in freshwater ecosystems: a meta-analysis. Global Change Biology, 22: 180-189.

Johnson MD, Sherry TW. 2001. Effects of food availability on the distribution of migratory warblers among habitats in Jamaica. Journal of Animal Ecology, 70(4): 546-560.

Johnson C. 2006. Australia's mammal extinctions: a 50,000-year history. Cambridge University Press.

Johnstone CP, Lill A, Reina RD. 2012. Does habitat fragmentation cause stress in the agile antechinus? A haematological approach. Journal of Comparative Physiology B, 182(1): 139-155.

Jokimäki J, Kaisanlahti-Jokimäki ML, Suhonen J, Clergeau P, Pautasso M, FernándezJuricic E. 2011. Merging wildlife community ecology with animal behavioral ecology for a better urban landscape planning. Landscape and Urban Planning, 100(4): 383-385.

Jones IC, Vinson GP, Jarrett IG, Sharman GB. 1964. Steroid components in the adrenal venous blood of Trichosurus vulpecula (Kerr). Journal of Endocrinology, 30(1): 149-150.

Jones ME, Apfelbach R, Banks PB, Cameron EZ, Dickman CR, Frank A, McLean S, McGregor IS, M“uller-Schwarze D, Parsons MH, Sparrow EA, Blumstein DT. 2016. A nose for death: integrating trophic and informational networks for conservation and management. Frontiers in Ecology and Evolution, 4: 124. DOI: 10.3389/fevo.2016.00124.

Kauffman MJ, Brodie JF, Jules ES. 2010. Are wolves saving Yellowstone's aspen? A landscape-level test of a behaviorally mediated trophic cascade. Ecology, 91(9): 2742-2755.

King JM, Bradshaw SD. 2010. Stress in an island kangaroo? The Barrow Island euro, Macropus robustus isabellinus. General and Comparative Endocrinology, 167(1): 60-67.

Klecka J, Boukal DS. 2014. The effect of habitat structure on prey mortality depends on predator and prey microhabitat use. Oecologia, 176(1): 183-191.

Kloppers EL, St. Clair CC, Hurd TE. 2005. Predator-resembling aversive conditioning for managing habituated wildlife. Ecology and Society, 10(1): 31.

Knutie SA. 2020. Food supplementation affects gut microbiota and immunological resistance to parasites in a wild bird species. bioRxiv, DOI: 10.1111/1365-2664.13567.

Peer) reviewing PDF | (2019:09:41203:3:0:NEW 9 Apr 2020) 
1010 Kohl MT, Stahler DR, Metz MC, Forester JD, Kauffman MJ, Varley N, White PJ, Smith 1011 DW, MacNulty DR. 2018. Diel predator activity drives a dynamic landscape of fear. Ecological 1012 Monographs, 88:638-652. DOI: 10.1002/ecm.1313.

1013 Kotler BP, Brown JS. 1988. Environmental heterogeneity and the coexistence of desert 1014 rodents. Annual Review of Ecology and Systematics, 19(1): 281-307.

1015 Kuijper DP, Bubnicki JW, Churski M, Mols B, Van Hooft P. 2015. Context dependence of risk effects: wolves and tree logs create patches of fear in an old-growth forest. Behavioral 1017 Ecology, 26(6): 1558-1568.

Labar KS, Ledoux JE. 2011. Coping with danger: the neural basis of defensive behavior and fearful feelings. Comprehensive Physiology, 8: 139 - 154.

Latham ADM, Latham MC, Boyce MS, Boutin S. 2011. Movement responses by wolves to industrial linear features and their effect on woodland caribou in northeastern Alberta. Ecological Applications, 21(8): 2854-2865.

Laundré JW, Hernández L, Altendorf KB. 2001. Wolves, elk, and bison: reestablishing the" landscape of fear" in Yellowstone National Park, USA. Canadian Journal of Zoology, 79(8): 1401-1409.

Laundré JW, Hernández L, Ripple WJ. 2010. The landscape of fear: ecological implications of being afraid. Open Ecology Journal, 3:1-7.

Laundré JW, Hernández L, Medina PL, Campanella A, López-Portillo J, GonzálezRomero A, Grajales-Tam KM, Burke AM, Gronemeyer P, Browning DM. 2014. The landscape of fear: the missing link to understand top-down and bottom-up controls of prey abundance? Ecology, 95(5): 1141-1152.

Laws AN. 2017. Climate change effects on predator-prey interactions. Current Opinion in Insect Science, 23: 28-34.

Leahy L, Legge SM, Tuft K, McGregor HW, Barmuta LA, Jones ME, Johnson CN. 2016. Amplified predation after fire suppresses rodent populations in Australia's tropical savannas. Wildlife Research, 42(8): 705-716.

LeDoux JE. 1996. The Emotional Brain, Simon and Schuster, New York.

LeDoux JE. 2003. The emotional brain, fear, and the amygdala, Cell and Molecular Neurobiology, 23: 727-738. threats affect conservation management outcomes: Livestock grazing removes the benefits of fire 
1044 Leighton PA, Horrocks JA, Kramer DL. 2010. Conservation and the scarecrow effect: Can 1045 human activity benefit threatened species by displacing predators? Biological Conservation, 1046 143(9): 2156-2163.

1047 Leo V, Reading RP, Letnic M. 2015. Interference competition: odours of an apex predator and 1048 conspecifics influence resource acquisition by red foxes. Oecologia, 179(4): 1033-1040.

Lima SL, Dill LM. 1990. Behavioral decisions made under the risk of predation: a review and prospectus. Canadian Journal of Zoology, 68(4): 619-640.

1051

1052

1053

1054

1055

1056

1057

1058

1059

1060

1061

1062

1063

1064

1065

1066

1067

1068

1069

1070

1071

1072

1073

1074

1075

1076

1077

Lima SL. 1998. Stress and decision making under the risk of predation: recent developments from behavioral, reproductive, and ecological perspectives. Advances in the Study of Behavior, 27: 215-290.

Lima SL, Bednekoff PA. 1999. Temporal variation in danger drives antipredator behavior: the predation risk allocation hypothesis. The American Naturalist, 153(6): 649-659.

Lone K, Loe LE, Gobakken T, Linnell JD, Odden J, Remmen J, Mysterud A. 2014. Living and dying in a multi-predator landscape of fear: roe deer are squeezed by contrasting pattern of predation risk imposed by lynx and humans. Oikos, 123(6): 641-651.

Lowry H, Lill A, Wong BBM. 2012. Behavioural responses of wildlife to urban environments, Biological Reviews, 88: 537-549.

Lyons J, Mastromonaco G, Edwards DB, Schulte-Hostedde AI. 2017. Fat and happy in the city: Eastern chipmunks in urban environments. Behavioural Ecology, 28(6): 1464-1471.

Ma Z, Becker DR, Kilgore MA. 2009. Assessing cumulative impacts within state environmental review frameworks in the United States. Environmental Impact Assessment Review, 29(6): 390-398.

MacDougall-Shackleton SA, Bonier F, Romero LM, Moore IT. 2019. Glucocorticoids and "stress" are not synonymous. Integrative Organismal Biology, 1(1): obz017, https://doiorg.ezproxy1.library.usyd.edu.au/10.1093/iob/obz017

Madsen B, Carroll N, Moore Brands K. 2010. State of Biodiversity Markets Report: Offset and Compensation Programs Worldwide, available at:

http://www.ecosystemmarketplace.com/documents/acrobat/sbdmr.pdf

Malcolm KD, McShea WJ, Garshelis DL, Luo SJ, Van Deelen TR, Liu F, Li S, Miao L, Wang D, Brown JL. 2014. Increased stress in Asiatic black bears relates to food limitation, crop raiding, and foraging beyond nature reserve boundaries in China. Global Ecology and Conservation, 2: 267-276.

Manuck SB, Kaplan JR, Adams MR, Clarkson TB. 1988. Studies of psychosocial influences on coronary artery atherogenesis in cynomolgus monkeys. Health Psychology, 7(2): 113. 
1078 Maren S. 2001. Neurobiology of Pavlovian fear conditioning. Annual Review of Neuroscience, 1079 24(1): 897-931.

1080

1081

1082

1083

1084

1085

1086

1087

1088

1089

1090

1091

1092

1093

1094

1095

1096

1097

1098

1099

1100

1101

1102

1103

1104

1105

1106

1107

1108

1109

1110

Mason JW. 1971. A re-evaluation of the concept of 'non-specificity' in stress theory. Journal of Psychiatric Research, 8(3-4): 323-333.

McCauley LA, Jenkins DG, Quintana-Ascencio PF. 2013. Isolated wetland loss and degredation over two decades in an increasingly urbanised landscape. Wetlands, 33(1): 117-127.

McClennen NA, Wigglesworth RR, Anderson SH, Wachob DG. 2001. The effect of suburban and agricultural development on the activity patterns of coyotes (Canis latrans). The American Midland Naturalist, 146(1): 27-37.

McComb LB, Lentini PE, Harley DK, Lumsden LF, Antrobus JS, Eyre AC, Briscoe NJ. 2019. Feral cat predation on Leadbeater's possum (Gymnobelideus leadbeateri) and observations of arboreal hunting at nest boxes. Australian Mammalogy, 41(2): 262-265.

McDonnell MJ, Hahs AK. 2015. Adaptation and adaptedness of organisms to urban environments. Annual Review of Ecology, Evolution, and Systematics, 46: 261-280.

McEwen BS, Stellar E. 1993. Stress and the individual: mechanisms leading to disease. Archives of Internal Medicine, 153(18): 2093-2101.

McEwen BS, Wingfield JC. 2003. The concept of allostasis in biology and biomedicine. Hormones and Behavior, 43(1): 2-15.

McEwen BS, 2004. Protection and damage from acute and chronic stress: allostasis and allostatic overload and relevance to the pathophysiology of psychiatric disorders. Annals of the New York Academy of Sciences, 1032(1): 1-7.

McKinney ML. 2006. Urbanization as a major cause of biotic homogenization. Biological Conservation, 127(3): 247-260.

McMahon JD, Lashley MA, Brooks CP, Barton BT. 2018. Covariance between predation risk and nutritional preferences confounds interpretations of giving-up density experiments. Ecology, 99(7), 1517-1522.

Mella VSA, Banks PB, McArthur C. 2014. Negotiating multiple cues of predation risk in a landscape of fear: what scares free-ranging brushtail possums? Journal of Zoology, 294(1): 2230 .

Mineka S. 1979. The role of fear in theories of avoidance learning, flooding, and extinction. Psychological Bulletin, 86(5): 985.

Mineur YS, Belzung C, Crusio WE. 2006. Effects of unpredictable chronic mild stress on anxiety and depression-like behavior in mice. Behavioural Brain Research, 175(1): 43-50. 
1111

1112

1113

1114

1115

1116

1117

1118

1119

1120

1121

1122

1123

1124

1125

1126

1127

1128

1129

1130

1131

1132

1133

1134

1135

1136

1137

1138

1139

1140

1141

1142

1143

Møller AP. 2009. Successful city dwellers: a comparative study of the ecological characteristics of urban birds in the Western Palearctic. Oecologia, 159(4): 849-858.

Morgan SA, Hansen CM, Ross JG, Hickling GJ, Ogilvie SC, Paterson AM. 2009. Urban cat (Felis catus) movement and predation activity associated with a wetland reserve in New Zealand. Wildlife Research, 36(7): 574-580.

Murray MH, Becker DJ, Hall RJ, Herandez SM. 2016. Wildlife health and supplemental feeding: A review and management recommendations. Biological Conservation, 204: 163-174.

Navara KJ, Nelson RJ. 2007. The dark side of light at night: physiological, epidemiological, and ecological consequences. Journal of Pineal Research, 43(3): 215-224.

Newsome TM, Ballard GA, Fleming PJ, van de Ven R, Story GL, Dickman CR. 2014. Human-resource subsidies alter the dietary preferences of a mammalian top predator. Oecologia, 175(1): 139-150.

Newsome TM, Dellinger JA, Pavey CR, Ripple WJ, Shores CR, Wirsing AJ, Dickman CR. 2015. The ecological effects of providing resource subsidies to predators. Global Ecology and Biogeography, 24(1): 1-11.

Newsome T, van Eeden L, Lazenby B, Dickman C. 2017. Does culling work? Australasian Science, 38(1): 28-30.

Nersesian CL, Banks PB, McArthur C. 2012. Behavioural responses to indirect and direct predator cues by a mammalian herbivore, the common brushtail possum. Behavioral Ecology and Sociobiology, 66(1): 47-55.

Norton DA. 2009. Species invasions and the limits to restoration: learning from the New Zealand experience. Science, 325(5940): 569-571.

Öhman A. 2000. In G. Fink (Ed.), Encyclopedia of stress (Vol. 2), Academic Press.

Otto SP. 2018. Adaptation, speciation and extinction in the Anthropocene. Proceedings of the Royal Society B, 285(1891): 20182047.

Palme R. 2019. Non-invasive measurement of glucocorticoids: Advances and problems. Physiology and Behaviour, 199: 229-243.

Palmer MA, Menninger HL, Bernhardt E. 2010. River restoration, habitat heterogeneity and biodiversity: a failure of theory or practice?. Freshwater Biology, 55: 205-222.

Parsons MH, Blumstein DT. 2010. Familiarity breeds contempt: kangaroos persistently avoid areas with experimentally deployed dingo scents. PLoS ONE, 5(5): $5 \mathrm{e} 10403$.

Parsons MH, Apfelbach R, Banks PB, Cameron EZ, Dickman CR, Frank AS, Jones ME, McGregor IS, McLean S, Müller-Schwarze D, Sparrow EE, Blumstein DT. 2017. 
1144 Biologically meaningful scents: a framework for understanding predator-prey research across

1145

1146

1147

1148

1149

1150

1151

1152

1153

1154

1155

1156

1157

1158

1159

1160

1161

1162

1163

1164

1165

1166

1167

1168

1169

1170

1171

1172

1173

1174

1175

1176

1177

disciplines. Biological Reviews. 93(1): 98-114. doi: 10.1111/brv.12334.

Parris KM. 2016. Ecology of urban environments. John Wiley and Sons.

Patten MA, Burger JC. 2018. Reserves as double-edged sword: Avoidance behavior in an urban-adjacent wildland. Biological Conservation, 218: 233-239.

Pianka ER. 2011. Evolutionary ecology. Eric R. Pianka.

Pickett ST, Cadenasso ML, Grove JM, Nilon CH, Pouyat RV, Zipperer WC, Costanza R. 2001. Urban ecological systems: linking terrestrial ecological, physical, and socioeconomic components of metropolitan areas. Annual Review of Ecology and Systematics, 32(1): 127-157.

Pitkanen A. 2000. Connectivity of the rat amygdaloid complex. The amygdala: A functional analysis. Oxford University Press, Oxford: 31-115.

Polis GA, Barnes JD, Seely MK, Henschel JR, Enders MM. 1998. Predation as a major cost of reproduction in Namib Desert tenebrionid beetles. Ecology, 79(7): 2560-2566.

Price CJ, Banks PB. 2018. Habitat augmentation for introduced urban wildlife: the use of piles of railway sleepers as refuge for introduced black rats Rattus rattus. Australian Zoologist, 39(3): 513-519.

Prugh LR, Stoner CJ, Epps CW, Bean WT, Ripple WJ, Laliberte AS, Brashares JS. 2009. The rise of the mesopredator. Bioscience, 59(9): 779-791.

Rayner MJ, Hauber ME, Imber MJ, Stamp RK, Clout MN. 2007. Spatial heterogeneity of mesopredator release within an oceanic island system. Proceedings of the National Academy of Sciences USA, 104(52): 20862-20865.

Rehnus M, Wehrle M, Palme R. 2014. Mountain hares Lepus timidus and tourism: stress events and reactions. Journal of Applied Ecology, 51(1): 6-12.

Rescorla RA, Solomon RL. 1967. Two-process learning theory: Relationships between Pavlovian conditioning and instrumental learning. Psychological Review, 74(3): 151.

Rieucau G, Vickery WL, Doucet GJ. 2009. A patch use model to separate effects of foraging costs on giving-up densities: an experiment with white-tailed deer (Odocoileus virginianus). Behavioral Ecology and Sociobiology, 63(6): 891-897.

Riley SP, Sauvajot RM, Fuller TK, York EC, Kamradt DA, Bromley C, Wayne RK. 2003. Effects of urbanization and habitat fragmentation on bobcats and coyotes in southern California. Conservation Biology, 17(2): 566-576.

Riley S, Brown J, Sikich J, Schoonmaker C, Boydston E. 2014. Wildlife friendly roads: the impacts of roads on wildlife in urban areas and potential remedies. In: McCleery R, Moorman C, Peterson M. (eds) Urban Wildlife Conservation. Springer, Boston, MA, pp. 323- 360.

Peerj reviewing PDF | (2019:09:41203:3:0:NEW 9 Apr 2020) 
1178

1179

1180

1181

1182

1183

1184

1185

1186

1187

1188

1189

1190

1191

1192

1193

1194

1195

1196

1197

1198

1199

1200

1201

1202

1203

1204

1205

1206

1207

1208

1209

1210

1211

1212

Ripple WJ, Estes JA, Beschta RL, Wilmers CC, Ritchie EG, Hebblewhite M, Berger J, Elmhagen B, Letnic M, Nelson MP, Schmitz OJ, Smith DW, Wallach AD, Wirsing AJ. 2014. Status and ecological effects of the world's largest carnivores. Science, 343(6167): 1241484.

Ritchie EG, Johnson CN. 2009. Predator interactions, mesopredator release and biodiversity conservation. Ecology Letters, 12(9): 982-998.

Rodríguez A, Andrén H, Jansson G. 2001. Habitat-mediated predation risk and decision making of small birds at forest edges. Oikos, 95(3): 383-396.

Rodrigues SM, LeDoux JE, Sapolsky RM. 2009. The influence of stress hormones on fear circuitry. Annual Review of Neuroscience, 32: 289-313.

Rodriguez A, Hausberger M, Clergeau P. 2010. Flexibility in European starlings' use of social information: experiments with decoys in different populations. Animal Behaviour, 80(6): 965973.

Romero LM. 2004. Physiological stress in ecology: lessons from biomedical research. Trends in Ecology \& Evolution, 19(5): 249-255.

Romero LM, Dickens MJ, Cyr NE. 2009. The reactive scope model - a new model integrating homeostasis, allostasis, and stress. Hormones and Behavior, 55(3), 375-389.

Roozendaal B. 2000. Glucocorticoids and the regulation of memory consolidation. Psychoneuroendocrinology, 25(3): 213-238.

Rosen JB, Schulkin J. 1998. From normal fear to pathological anxiety. Psychological Review, 105(2): 325-350.

Rosen JB. 2004. The neurobiology of conditioned and unconditioned fear: a neurobehavioral system analysis of the amygdala. Behavioral and Cognitive Neuroscience Reviews, 3(1): 23-41.

Rosen JB, Schulkin J. 2004. Adaptive fear, allostasis, and the pathology of anxiety and depression. Allostasis, Homeostasis and the Costs of Physiological Adaptation: 164-227.

Santini L, González-Suárez M, Russo D, Gonzalez-Voyer A, von Hardenberg A, Ancillotto L. 2019. One strategy does not fit all: determinants of urban adaptation in mammals. Ecology Letters, 22(2): 365-376.

Santos X, Mateos E, Bros V, Brotons L, De Mas E, Herraiz JA, Herrando S, Miňo À, Olmo-Vidal JM, Quesada J, Ribes J, Sabaté S, Sauras-Yera T, Serra A, Vallejo VR, Viňolas A. 2014. Is response to fire influenced by dietary specialization and mobility? A comparative study with multiple animal assemblages. PLoS ONE, 9(2): e88224.

Salo P, Korpimäki E, Banks PB, Nordström M, Dickman CR. 2007. Alien predators are more dangerous than native predators to prey populations. Proceedings of the Royal Society of London B: Biological Sciences, 274(1615): 1237-1243.

Peer) reviewing PDF | (2019:09:41203:3:0:NEW 9 Apr 2020) 
1213 Sapolsky RM, Romero LM, Munck AU. 2000. How do glucocorticoids influence stress 1214 responses? Integrating permissive, suppressive, stimulatory, and preparative actions. Endocrine 1215 Reviews, 21(1): 55-89.

1216

1217

1218

1219

1220

1221

1222

1223

1224

1225

1226

1227

1228

1229

1230

1231

1232

1233

1234

1235

1236

1237

1238

1239

1240

1241

1242

1243

1244

1245

1246

1247

Say-Sallaz E, Chamaillé-Jammes S, Fritz H, Valeix M. 2019. Non-consumptive effects of predation in large terrestrial mammals: Mapping our knowledge and revealing the tip of the iceberg. Biological Conservation, 235:36-52. DOI: 10.1016/j.biocon.2019.03.044.

Schell CJ, Young JK, Lonsdorf EV, Santymire RM, Mateo JM. 2018. Parental habituation to human disturbance over time reduces fear of humans in coyote offspring. Ecology and Evolution, 8(24), 12965-12980.

Schmidt K, Kuijper DP. 2015. A "death trap" in the landscape of fear. Mammal Research, 60(4): 275-284.

Schmitz OJ, Beckerman AP, O'Brien KM. 1997. Behaviorally mediated trophic cascades: effects of predation risk on food web interactions. Ecology, 78:1388-1399.

Schmitz OJ, Krivan V, Ovadia O. 2004. Trophic cascades: the primacy of trait-mediated indirect interactions. Ecology Letters, 7(2): 153-163.

Schmitz OJ. 2008. Effects of predator hunting mode on grassland ecosystem function. Science, 319(5865): 952-954.

Schulkin J, Thompson BL, Rosen JB. 2003. Demythologizing the emotions: adaptation, cognition, and visceral representations of emotion in the nervous system. Brain and Cognition, 52(1): 15-23.

\section{Sergio F, Caro T, Brown D, Clucas B, Hunter J, Ketchum J, McHugh K, Hiraldo}

F. 2008. Top predators as conservation tools: ecological rationale, assumptions, and efficacy. Annual Review of Ecology, Evolution and Systematics 39: 1- 19.

Seyle H. 1936. A syndrome produced by diverse noxious agents. Nature (London), 138: 32-39.

Shannon G, McKenna MF, Angeloni LM, Crooks KR, Fristrup KM, Brown E, Warner KA, Nelson MD, White C, Briggs J, McFarland S. 2016. A synthesis of two decades of research documenting the effects of noise on wildlife. Biological Reviews, 91(4): 982-1005.

Sheriff MJ, Dantzer B, Delehanty B, Palme R, Boonstra R. 2011. Measuring stress in wildlife: techniques for quantifying glucocorticoids. Oecologia, 166(4): 869-887.

Sherman LJ. 1984. The effects of patchy food availability on nest-site selection and movement patterns of reproductively active female meadow voles Microtus pennsylvanicus. Ecography, 7(3): 294-299.

Shochat E, Lerman S, Fernández-Juricic E. 2010. Birds in urban ecosystems: population dynamics, community structure, biodiversity, and conservation. Urban ecosystem ecology, (urbanecosysteme):75-86. 
1248

1249

1250

1251

1252

1253

1254

1255

1256

1257

1258

1259

1260

1261

1262

1263

1264

1265

1266

1267

1268

1269

1270

1271

1272

1273

1274

1275

1276

1277

1278

1279

1280

1281

Shrader AM, Brown JS, Kerley GI, Kotler BP. 2008. Do free-ranging domestic goats show 'landscapes of fear'? Patch use in response to habitat features and predator cues. Journal of Arid Environments, 72: 1811-1819.

Sinclair ARE, Arcese P. 1995. Population consequences of predation-sensitive foraging: The Serengeti wildebeest. Ecology, 76(3): 882-891.

Smit B, Spaling H. 1995. Methods for cumulative effects assessment. Environmental Impact Assessment Review, 15(1): 81-106.

Smith JA, Suraci JP, Clinchy M, Crawford A, Roberts D, Zanette LY, Wilmers CC. 2017. Fear of the human "super predator" reduces feeding time in large carnivores. Proceedings of the Royal Society B: Biological Sciences, 284:20170433. DOI: 10.1098/rspb.2017.0433.

Smith JA, Donadio E, Pauli JN, Sheriff MJ, Middleton AD. 2019. Integrating temporal refugia into landscapes of fear: prey exploit predator downtimes to forage in risky places. Oecologia, 189:883-890. DOI: 10.1007/s00442-019-04381-5.

Snell-Rood EC, Wick N. 2013. Anthropogenic environments exert variable selection on cranial capacity in mammals. Proceedings of the Royal Society B: Biological Sciences, 280(1769): 20131384.

Soso SB, Koziel JA, Johnson A, Lee YJ, Fairbanks WS. 2014. Analytical methods for chemical and sensory characterization of scent-markings in large wild mammals: a review. Sensors, 14: 4428-4465.

Spencer EE, Crowther MS, Dickman CR. 2014. Risky business: do native rodents use habitat and odor cues to manage predation risk in Australian deserts?. PLoS ONE, 9(2): e90566.

Stankowich T. 2008. Ungulate flight responses to human disturbance: a review and metaanalysis. Biological Conservation, 141(9): 2159-2173.

Sterling P, Eyer J. 1988. Allostasis: a new paradigm to explain arousal pathology. In 'Handbook of Life Stress, Cognition and Health'(Eds K. Fisher and J. Reason.): 629-649.

Stillfried M, Fickel J, Börner K, Wittstatt U, Heddergott M, Ortmann S, Kramer-Schadt S, Frantz AC. 2017. Do cities represent sources, sinks or isolated islands for urban wild boar population structure? Journal of Applied Ecology, 54(1): 272-281.

Suraci JP, Clinchy M, Zanette LY, Wilmers CC. 2019. Fear of humans as apex predators has landscape-scale impacts from mountain lions to mice. Ecology Letters. DOI: 10.1111/ele.13344.

Tablado Z, Jenni L. 2017. Determinants of uncertainty in wildlife responses to human disturbance. Biological Reviews, 92: 216-233.

Taylor-Brown A, Booth R, Gillett A, Mealy E, Ogbourne SM, Polkinghorne A, Conroy GC. 2019. The impact of human activities on Australian wildlife. PLOS ONE, 14(1): e0206958.

Peer] reviewing PDF | (2019:09:41203:3:0:NEW 9 Apr 2020) 
1282 Tews J, Brose U, Grimm V, Tielbörger K, Wichmann MC, Schwager M, Jeltsch F. 2004.

1283 Animal species diversity driven by habitat heterogeneity/diversity: the importance of keystone 1284 structures. Journal of Biogeography, 31(1): 79-92.

1285

1286

1287

1288

1289

1290

1291

1292

1293

1294

1295

1296

1297

1298

1299

1300

1301

1302

1303

1304

1305

1306

1307

1308

1309

1310

1311

1312

1313

1314

Therivel R, Ross B. 2007. Cumulative effects assessment: does scale matter? Environmental Impact Assessment Review, 27(5): 365-385.

Threlfall CG, Williams NS, Hahs AK, Livesley SJ. 2016. Approaches to urban vegetation management and the impacts on urban bird and bat assemblages. Landscape and Urban Planning, 153: 28-39.

Tigas LA, Van Vuren DH, Sauvajot RM. 2002. Behavioral responses of bobcats and coyotes to habitat fragmentation and corridors in an urban environment. Biological Conservation, 108(3): 299-306.

Tooby J, Cosmides L. 1990. The past explains the present: emotional adaptations and the structure of ancestral environments. Ethology and Sociobiology, 11(4-5): 375-424.

Støen OG, Ordiz A, Evans AL, Laske TG, Kindberg J, Fröbert O, Swenson JE, Arnemo JM. 2015. Physiological evidence for a human-induced landscape of fear in brown bears (Ursus arctos). Physiology \& Behavior, 152(A): 244-248.

Sweitzer RA. 1996. Predation or starvation: consequences of foraging decisions by porcupines (Erethizon dorsatum). Journal of Mammalogy, 77(4): 1068-1077.

Thomson RL, Tomás G, Forsman JT, Broggi J, Mönkkönen M. 2010. Predator proximity as a stressor in breeding flycatchers: mass loss, stress protein induction, and elevated provisioning. Ecology, 91(6): 1832-1840.

Threlfall CG, Law B, Banks PB. 2012. Influence of landscape structure and human modifications on insect biomass and bat foraging activity in an urban landscape. PLoS ONE, 7(6): e38800.

Towerton AL, Penman TD, Kavanagh RP, Dickman CR. 2011. Detecting pest and prey responses to fox control across the landscape using remote cameras. Wildlife Research, 38(3): 208-220.

Travers M, Clinchy M, Zanette L, Boonstra R, Williams TD. 2010. Indirect predator effects on clutch size and the cost of egg production. Ecology Letters, 13(8): 980-988.

Trussell GC, Ewanchuk PJ, Matassa CM. 2006. Habitat effects on the relative importance of trait-and density-mediated indirect interactions. Ecology Letters, 9(11): 1245-1252.

Turcotte Y, Desrochers A. 2003. Landscape-dependent response to predation risk by forest birds. Oikos, 100(3): 614-618. 
Van Buskirk J, Müller C, Portmann A, Surbeck M. 2002. A test of the risk allocation hypothesis: tadpole responses to temporal change in predation risk. Behavioral Ecology, 13(4): 526-530.

Van Der Merwe M, Brown JS. 2008. Mapping the landscape of fear of the cape ground squirrel (Xerus inauris). Journal of Mammalogy, 89(5): 1162-1169.

Vijayakrishnan S, Kumar MA, Umapathy G, Kumar V, Sinha A. 2018. Physiological stress responses in wild Asian elephants Elephas maximus in a human-dominated landscape in the Western Ghats, southern India. General and Comparative Endocrinology. DOI: 10.1016/j.ygcen.2018.05.009.

Wallace KJ, Rosen JB. 2000. Predator odor as an unconditioned fear stimulus in rats: elicitation of freezing by trimethylthiazoline, a component of fox feces. Behavioral Neuroscience, 114(5): 912-922.

Wallace KJ, Rosen JB. 2001. Neurotoxic lesions of the lateral nucleus of the amygdala decrease conditioned fear but not unconditioned fear of a predator odor: comparison with electrolytic lesions. Journal of Neuroscience, 21(10): 3619-3627.

Warburton B, Norton BG. 2009. Towards a knowledge-based ethic for lethal control of nuisance wildlife. Journal of Wildlife Management, 73(1): 158-164.

Weissburg M, Smee DL, Ferner MC. 2014. The sensory ecology of nonconsumptive predator effects. The American Naturalist, 184(2): 141-157.

Werner EE, Peacor SD. 2003. A review of trait-mediated indirect interactions in ecological communities. Ecology, 84(5): 1083-1100.

Western D. 2001. Human-modified ecosystems and future evolution. Proceedings of the National Academy of Sciences USA, 98(10): 5458-5465.

Willems EP, Hill RA. 2009. Predator-specific landscapes of fear and resource distribution: effects on spatial range use. Ecology, 90(2): 546-555.

Wingfield JC, Kitaysky AS. 2002. Endocrine responses to unpredictable environmental events: stress or anti-stress hormones? Integrative and Comparative Biology, 42(3): 600-609.

Woinarski JC, Burbidge AA, Harrison PL. 2015. Ongoing unraveling of a continental fauna: decline and extinction of Australian mammals since European settlement. Proceedings of the National Academy of Sciences USA, 112(15): 4531-4540.

Yates FE, Russell SM, Maran JW. 1971. Brain-adenohypophysial communication in mammals. Annual Review of Physiology, 33(1): 393-444.

Zanette LY, White AF, Allen MC, Clinchy M. 2011. Perceived predation risk reduces the number of offspring songbirds produce per year. Science, 334(6061): 1398-1401. 
1349 Zbyryt A, Bubnicki JW, Kuijper DPJ, Dehnhard M, Churski M, Schmidt K, Wong B. 1350 2017. Do wild ungulates experience higher stress with humans than with large carnivores? 1351 Behavioral Ecology. DOI: 10.1093/beheco/arx142.

1352 


\section{Figure 1}

A Venn diagram showing two main categories of stressor.

On the left are stressors that occur naturally in ecosystems, such as native predators, social and breeding interactions, availability of refuge and burrow/den microhabitats, disease / parasite prevalence, and availability of food and water. On the right are introduced stressors, primarily those arising from anthropogenic disturbances, such as: urban developments, human activity, introduced toxins and introduced predators. Where both categories of stressor occur together simultaneously, as in many urban environments, cumulative stress impacts can result in homeostatic overload or failure (as defined by Romero, Dickens, and Cyr, 2009). In these situations populations may be at particular risk of collapse and conservation action will be most urgent.

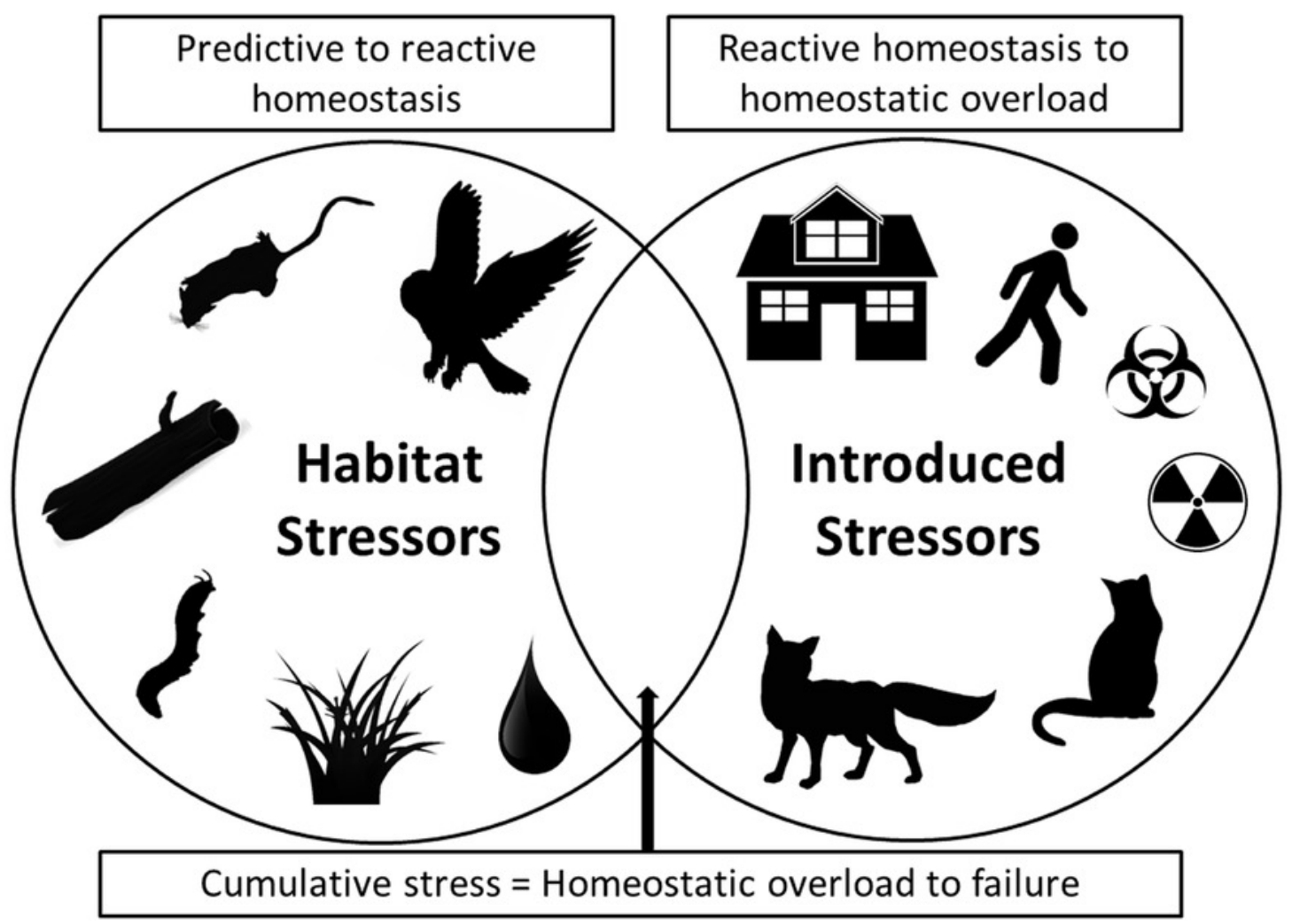


Figure 2

A conservation management approach that outlines the key steps for assessing if cumulative stress impacts are occurring between stressors that occur naturally in ecosystems and those that are introduced.

The circled areas indicate where conservation management initiatives may be used to mitigate these effects through management of vegetation complexity or supplementation materials such as water stations or carved 'tree-hollow' cavities.

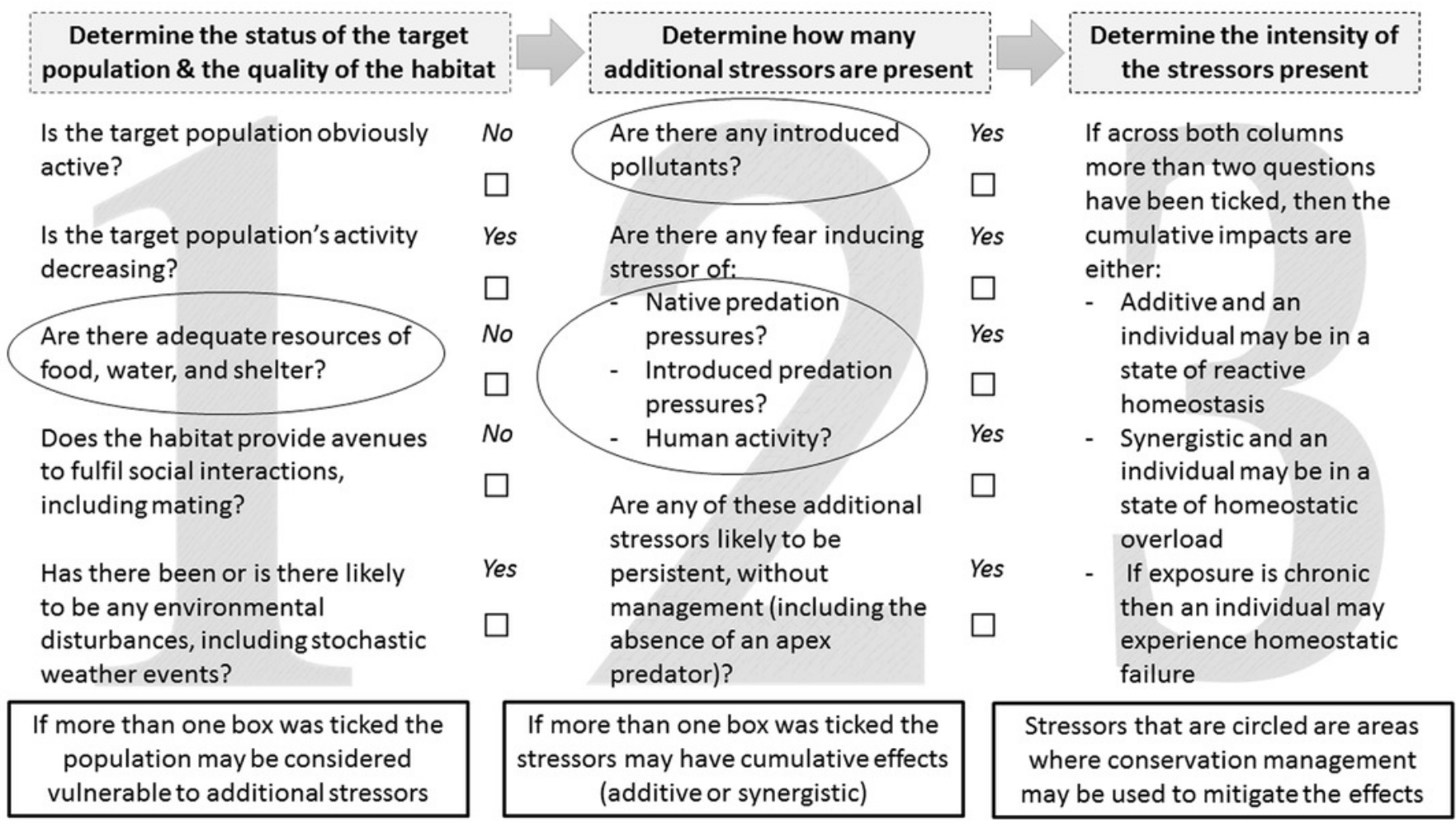


Figure 3

Graphical Abstract

Why wildlife conservation needs to measure: Fear and stressing in predator-prey ecology: considering the twin stressors of predators and people on mammals

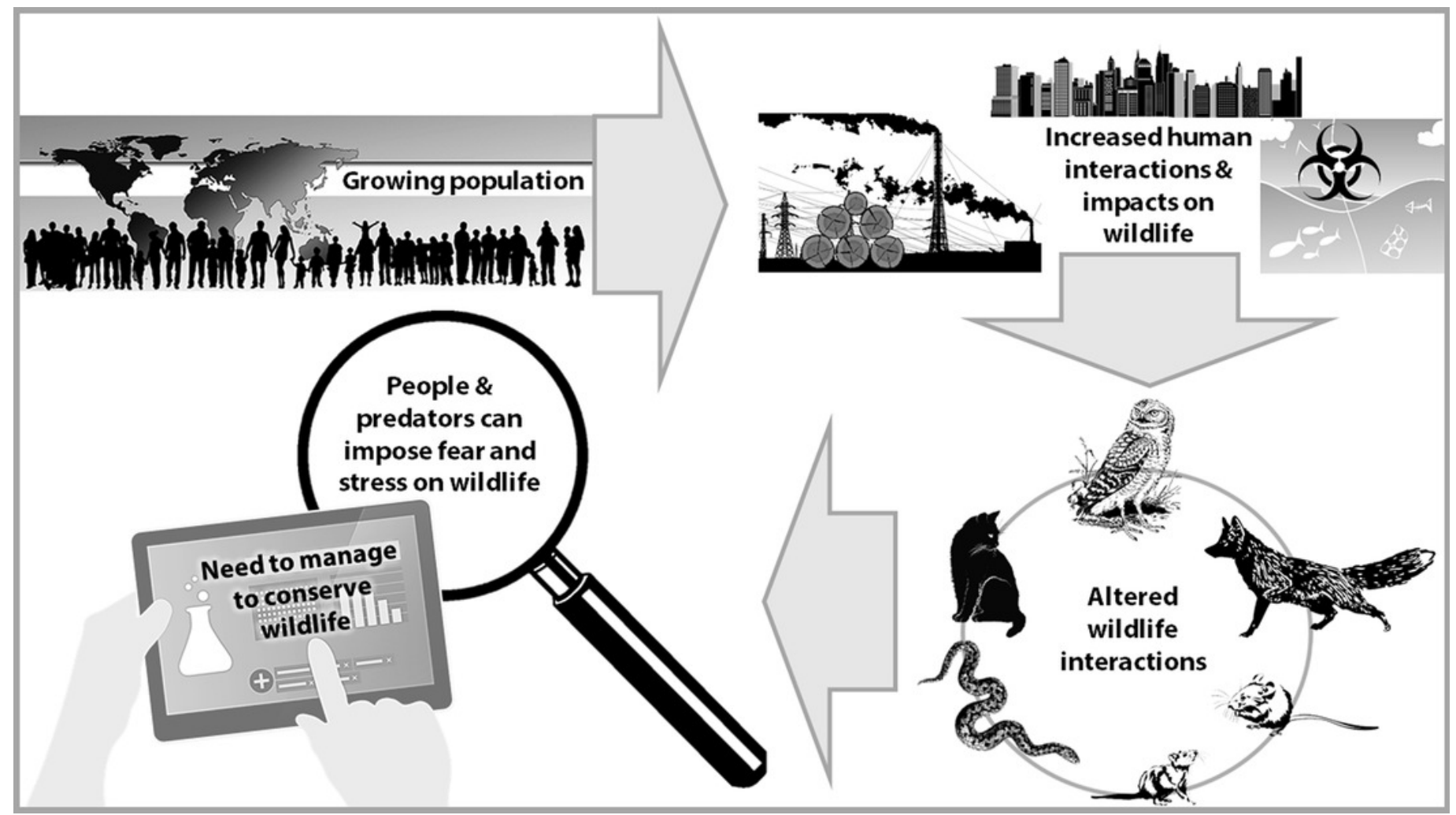

